\title{
A MANUTENÇÃO COMO FORMA DE PREVENÇÃO DE DOENÇAS ORIGINÁRIAS EM AMBIENTES CLIMATIZADOS
}

\author{
GUSTAVO MONTES NAKED
}

Dissertação apresentada ao Departamento de Saúde Ambiental da Faculdade de Saúde Pública da Universidade de São Paulo para obtenção do título de Mestre em Saúde Pública.

Área de concentração: Saúde Ambiental

Orientador - Prof. Dr. Carlos Celso Amaral e Silva

São Paulo

2005

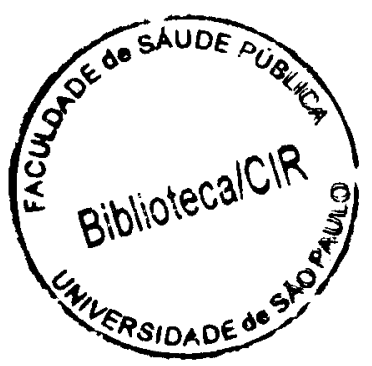


4575212005 doc

Autorizo. exclusivamente para fins acadêmicos a reprodução total ou parcial desta tese, por processos fotocopiadores.

Data: KeV/200s

Assinatura: Jutaw Loter Naled 


\section{AGRADECIMENTOS}

Aos meus pais, Darcy e Yazid, por contribuírem com extrema dedicação à minha formação, especialmente à minha mãe que, além de tudo, ainda realizou a correção desta dissertação.

À minha esposa Patrícia e meu filho Rafael, pelo incentivo e compreensão às ausências necessárias para a elaboração deste.

À Novartis, por disponibilizar o tempo requerido para a conclusão dos créditos e também por permitir a realização da coleta de dados aqui apresentados.

Ao Prof. Dr. Carlos Celso Amaral e Silva, pela orientação e apoio prestados para a concretização deste trabalho acadêmico. 


\section{RESUMO}

Em virtude da evolução dos conceitos e dos problemas relacionados com os sistemas de ar condicionado, o presente trabalho apresenta um histórico sobre os usos de sistemas e os possíveis impactos ligados ao funcionamento e à operação deles com a saúde pública.

São utilizados nos processos de manufatura que exigem umidade, temperatura e pureza do ar, na fabricação de produtos farmacêuticos e alimentícios, em ambientes de trabalho que requerem conforto, em locais onde se necessita de segurança na manipulação de produtos e na guarda de patrimônios culturais e históricos, entre outros.

Os principais impactos estão relacionados com o desconforto térmico e o desequilíbrio ambiental, podendo provocar danos aos produtos, ao patrimônio e sintomalogias, tais como: dores de cabeça, irritação nos olhos, na garganta e no nariz.

Este trabalho considera ainda a avaliação das legislações atuais que definem os critérios e requisitos para controle e operação de sistemas de ar condicionado, como forma de prevenção de doenças.

A avaliação das técnicas de manutenção comumente empregadas em equipamentos relacionados com ambientes climatizados e a apresentação dos efeitos mais comuns, provocados ao ambiente interior pela ineficiência daquelas, são os objetivos principais deste projeto.

Além dos resultados encontrados na bibliografia, também foram apresentados valores recentes, fruto de uma campanha de monitoramento, realizada 
em uma empresa, com o intuito de avaliar a eficácia das ações de manutenção empregadas e os possíveis riscos existentes.

Conclui-se, a partir da análise dos dados obtidos, que os processos de manutenção implementados de maneira adequada são os mais eficientes como forma de prevenção das doenças originárias em sistemas de ar condicionado. 


\section{SUMMARY}

Due to the development of concepts and problems related to air conditioning systems, the present project presents a study of usage of such systems and the possible impacts on public health due to their functioning and operation.

Within their usage, it is highlighted manufacturing processes that require humidity, temperature and air purity, in the production of pharmaceutical and food products, in work environments that require comfort, in places that need safety when manipulating products, in the storage of cultural and historical heritage, and many others.

The main impacts are related to thermal discomfort, environmental unbalance that may damage products, patrimony and also symptoms like: headache, irritability of eyes, nose and throat.

This project also considers the evaluation of current legislations that define the criteria and requirements for control and operation of air conditioning systems as means of preventing illnesses.

The main objectives of this project are the evaluation of maintenance techniques often employed in equipments related to acclimatized environments and the presentation of the most common effects to the internal environment caused by the inefficiency of such techniques. 
As well as the results found in the bibliography, recent studies from a monitoring campaign held in a company with the objective of evaluation of maintenance efficiency and possible existing risks are also presented.

From analyzing the data gathered it is concluded that maintenance processes implemented in an adequate manner are the most efficient as means of preventing illnesses originated in air conditioning systems. 


\section{Lista de Siglas:}

- $u f c / \mathrm{m}^{3}$ : unidades formadas de colônia por metro cúbico

- $\mathrm{m} / \mathrm{s}$ : metros por segundo

- p p m: partes por milhão

- $\mathrm{mg} / \mathrm{m}^{3}$ : miligramas por metro cúbico

- I / E: relação da concentração de fungos presentes no ambiente interno dividido pela concentração presente no ambiente externo

- PMOC: Programa de Manutenção, Operação de Controle 


\section{Lista de Tabelas:}

Tabela 01: Valores referentes à distribuição do comportamento microbiológico (fungos e bactérias) e material particulado, observados no retorno do ar do equipamento.

Tabela 02: Valores referentes à distribuição do comportamento microbiológico (fungos e bactérias) e material particulado, observados próximos ao sistema do ar condicionado.

Tabela 03: Valores referentes à distribuição do comportamento microbiológico (fungos e bactérias) e material bioparticulado, observados distantes do sistema de ar condicionado.

Tabela 04: Resultados de monitoramento da concentração de bactérias e fungos na água da bandeja do condensado, antes e depois do processo de higienização.

Tabela 05: Resultados de monitoramento da concentração de bactérias e fungos no biofilme da bandeja do condensado, antes e depois do processo de higienização.

Tabela 06: Média dos cinqüenta pontos obtidos nos resultados de monitoramento do sistema de ar condicionado.

Tabela 07: Média dos resultados de monitoramento obtidos no sistema de ar condicionado.

Tabela 08: Resultados de monitoramento obtidos para as análises de umidade e temperatura.

Tabela 09: Resultados de monitoramento obtidos para a velocidade do ar e concentração de $\mathrm{CO}_{2}$.

Tabela 10: Resultados de monitoramento dos valores para a concentração de fungos e de material particulado.

Tabela 11: Resultados dos valores obtidos para a relação I/E. 


\section{Lista de Gráficos:}

Gráfico 01: Concentração de poluentes amostrados no retorno do ar condicionado.

Gráfico 02: Concentração de poluentes amostrados próximo ao sistema de ar condicionado.

Gráfico 03: Concentração de poluentes coletados em um ponto distante do sistema de ar condicionado.

Gráfico 04: Concentração de bactérias presentes na água da bandeja de condensado antes e depois do processo de intervenção.

Gráfico 05: Concentração de bactérias presentes no biofilme da bandeja de condensado antes e depois do processo de intervenção.

Gráfico 06: Concentração de fungos presentes no biofilme da bandeja de condensado antes e depois do processo de intervenção.

Gráfico 07: Concentração de fungos presentes no sistema de ar condicionado.

Gráfico 08: Valor médio da concentração de fungos entre os cinqüenta pontos amostrados.

Gráfico 09: Resultados de monitoramento de umidade amostrados em 15 pontos.

Gráfico 10: Resultados de monitoramento de temperatura amostrados em 15 pontos.

Gráfico 11: Resultados de monitoramento da velocidade do ar amostrados em 15 pontos.

Gráfico 12: Resultados de monitoramento da concentração de dióxido de carbono amostrados em 15 pontos.

Gráfico 13: Resultados de monitoramento da concentração de fungos amostrados em 15 pontos.

Gráfico 14: Resultados de monitoramento da concentração de material particulado amostrados em 15 pontos.

Gráfico 15: Resultados de monitoramento da relação da concentração de fungos presentes no ambiente interior e no ar exterior calculado para os 15 pontos amostrados. 


\section{ÍNDICE}

1. INTRODUÇÃO 1

1.1- História, evolução dos conceitos e usos de sistemas de ar 1 condiconado

1.2- Principais poluentes, fontes e respectivos efeitos 7

1.2.1. Contaminantes Químicos 8

$\begin{array}{ll}\text { 1.2.2. Contaminantes Biológicos } & 12\end{array}$

$\begin{array}{ll}\text { 1.2.3. Contaminantes Físicos } & 14\end{array}$

1.3- Principais problemas e riscos envolvidos na operação e 17 funcionamento dos sitemas.

1.4- Os requisitos legais aplicáveis aos sistemas 25

1.5- A manutenção como forma de prevenção dos riscos 36

2. OBJETIVOS 43

3. METODOLOGIA 45

4. RESULTADOS 49

5. DISCUSSÃO 59

6. CONCLUSÃO 73

$\begin{array}{lll}\text { 7. BIBLIOGRAFIA } & 79\end{array}$ 


\section{INTRODUÇÃO}

\subsection{História, evolução dos conceitos e usos de sistemas de}

\section{ar condicionado}

O meio ambiente interior e a qualidade de ar vêm assumindo cada vez mais importante papel na Saúde Pública e na Saúde Ocupacional.

A partir da década de 30 , os ambientes condicionados artificialmente, isto é, aqueles que têm sua temperatura controlada através do uso de equipamentos específicos para este fim, foram colocados à disposição da humanidade, porém, nos primórdios (até a década de 70), as taxas de renovação não constituíam problema energético, não requerendo portanto um controle apurado do processo. Ainda durante este período, o conceito de poluição interior considerava apenas os riscos relacionados aos ocupantes como únicos poluentes, por exemplo, emissões de gases devido ao uso de cigarro e ao uso de produtos químicos em processos de limpeza.

A crise do petróleo, nos anos 70 , mudou os rumos do condicionamento de ambientes interiores, uma vez que a escassez e a limitação de uso fizeram que a economia de energia tornasse prioridade. Assim as taxas de renovação do ar obedeceram à proporcionalidade de quanto maior a quantidade de ar externo, maior o consumo de energia, causando significativo aumento nas taxas de recirculação.

$\mathrm{O}$ ar é o elemento, que de maneira contínua e permanente, independente de meios artificiais, mantém contato direto entre o ambiente ocupacional (pessoas, utensílios e outros) e o meio ambiente, mas, quando ignorado e mantido não 
corretamente, pode se tornar um verdadeiro transporte das seguintes variáveis de agressão à saúde e ao conforto: calor, água, fumaça, sujidade, poeira e odores.

Com significativo crescimento das áreas urbanizadas em todo o mundo, a maior parte das atividades humanas passou a ser realizada em ambientes interiores, cujo suprimento de ar depende de sistemas artificiais (TAKAHASHI, S, 1996). Por este motivo, é importante avaliar a qualidade de ar destes ambientes e estimar seus efeitos à saúde humana (YOTSUYANAGI, T, 1993).

A tecnologia buscou então reproduzir e melhorar as condições naturais de conforto, para permitir que o ser humano pudesse passar horas a fio em seus interiores. Essas condições artificiais demandam, porém, monitoramento e adequações constantes, sob pena de agravamento da qualidade de vida das pessoas. A sensação térmica de um ambiente pode ser alterada apenas com o aumento da velocidade do ar, como, quando alguém se coloca na frente de um ventilador, ou alternando a umidade relativa do ar, que é a sensação tida em certos dias de verão, quando o calor não está tão intenso, mas percebe-se que está abafado. Caso a temperatura não seja controlada de maneira adequada, bem como a umidade relativa e a velocidade do ar, não se consegue estabelecer o conforto térmico, tornando o ambiente insalubre, uma vez que a umidade relativa elevada facilita a proliferação de fungos e bactérias, através do crescimento microbiológico.

Desta forma, o sistema mecânico de controle das condições do ambiente interior adquiriu posição de hegemonia em relação ao sistema natural.

No ano de 1982, a O.M.S. (Organização Mundial de Saúde) definiu, em virtude do crescente número de agravos à saúde humana, a S.E.D. (Síndrome dos Edifícios Doentes), uma combinação de sintomas gerais que afetam diretamente os 
ocupantes de ambientes fechados, ao mesmo tempo em que foi batizada como "Doença do Ambiente Interno" - DAI (Building Related Illness), aquela causada devido às sintomatologias relacionadas a poluentes de origem física, química e biológica.

A hipersensibilidade, causada por exposição aos diversos contaminantes presentes no meio ambiente, pode produzir desordens respiratórias, desordens de pele e também desordens oculares.

No ano de 1985 a Organização Mundial de Saúde reconheceu o controle da qualidade de ar como um problema de Saúde Pública, nominando-o Indoor Air Quality (IAQ), referindo-se a uma relação de causa e efeito entre as condições ambientais de trabalho em decorrência de agressões ao bem-estar e conforto, observados nestes locais, promovendo altas taxas de absenteísmo e redução na produtividade do trabalhador.

Segundo a definição da American Society of Heating, Refrigerating and Air Conditionning Engineers "ar condicionado é o processo de tratamento de ar para controlar simultaneamente, temperatura, umidade, pureza e distribuição, objetivando atender às necessidades do recinto condicionado, ocupado ou não pelo homem".

Os principais fatores que provocam problemas correlacionados à síndrome dos edificios doentes, podem ser agrupados em sete itens:

a. Insuficiência de ar exterior: para ambientes comuns de trabalho ( por exemplo escritórios) a norma recomenda pelo menos $25 \mathrm{~m} 3 / \mathrm{h}$ de ar exterior por pessoa para garantir a correta renovação. 
b. Má distribuição do ar: além de não permitir que a correta taxa de renovação atinja os pontos necessários, a má distribuição do ar pode formar bolsões quentes e frios no ambiente. Um caso típico é o curto-circuito, freqüentemente observado, entre o insuflamento e a exaustão. Outro fator desencadeador, constante em escritórios, é a prática comum de se dividir ambientes que foram dimensionados para ser em vão livre, introduzindo divisórias, não planejadas, para a formação de pequenas salas e prejudicando a distribuição do ar.

c. Controle deficiente de temperatura: a colocação de termostato de controle em lugar errado pode ser uma causa das reclamações dos usuários. O exemplo é o uso do termostato no retorno da casa de máquinas e nos ambientes que possuem grandes diferenças de carga térmica.

d. Projeto inadequado: a tomada de ar exterior junto à rua, voltada para estacionamentos, onde há concentrações excessivas de $\mathrm{CO}$, é um bom exemplo de projeto inadequado. Outro erro comum é o posicionamento da tomada de ar externo junto a jardins, chaminés e exaustores.

e. Modificações inadequadas após construção: mudança das taxas de ocupação e / ou iluminação sem a análise da carga térmica.

f. Falta de manutenção dos sistemas: a falta de manutenção apropriada permite o acúmulo de material particulado que, além de aglomerar fatores físicos de agressão, tais como fibras e substâncias protéicas, é um substrato para a incubação de 
fungos e bactérias, desbalanceando as redes de insuflamento, promovendo a saturação dos filtros de ar, o surgimento de biofilme em bandejas e serpentinas, conduzindo a um aumento das fontes de poluentes e causando a deterioração precoce da instalação.

g. Falta de compreensão do funcionamento do sistema: a não compreensão do funcionamento do sistema, dos mecanismos de instalação, manutenção e difusão das fontes poluentes, tanto de origem biológica, química quanto fisica, pode induzir o mantenedor a atitudes desastrosas, colocando em perigo todo o desempenho do sistema e o impacto direto sobre a qualidade do ar do ambiente interior e a população usuária.

As instalações, contendo sistemas de ar condicionado, são encontradas em sua grande maioria:

- nos processos de manufatura, que exigem umidade, temperatura e pureza do ar controlado, como a fabricação de produtos farmacêuticos e alimentícios, salas de desenho de precisão, impressão em cores;

- em ambientes de trabalho, visando a aumentar o conforto do ser humano e, conseqüentemente, sua produtividade;

- em ambientes onde se exige segurança na manipulação de produtos inflamáveis e/ou tóxicos; 
- em ambientes onde se exige segurança na guarda de patrimônios culturais e históricos;

- em ambientes que necessitam de baixo risco de infectividade, tais como: salas cirúrgicas, unidades de tratamento intensivo, isolamentos, unidades de transplantes, unidades de queimados e outros;

- em ambientes onde se processam materiais higroscópicos;

- em etapas de produção que exigem controle de reações químicas ou biológicas, (cristalização, corrosão de metais, fermentação de microorganismos);

- em locais onde é necessário eliminar eletricidade estática e funcionamento de equipamentos sensíveis, ou para prevenir incêndios e explosões,

- em operações de usinagem com tolerância mínima para concentração de materiais particulados e

- em laboratórios de controle e testes de materiais.

Devido aos perigos relacionados à existência de um grande leque de variáveis que podem interferir nos processos e à tendência de crescimento do número de atividades realizadas em ambientes climatizados, as ações de controle ligadas ao sistema, com maior destaque para a movimentação no ambiente de trabalho e para 
ventilação mecânica, precisam ser criteriosamente planejadas, executadas e mantidas, com o intuito de garantir o controle de fatores adversos, relacionados à agressão à saúde humana, à segurança de patrimônios, à qualidade em processos e fluxos de produção.

Com foco em Saúde Pública, o presente trabalho descreverá os principais poluentes presentes em ambientes climatizados, suas fontes $\mathrm{e}$ as conseqüências, não se atentando aos riscos relacionados à segurança de patrimônios e eventuais impactos que estes contaminantes possam provocar na qualidade de processo ou ainda nos fluxos de produção.

Cabe destacar ainda que, apesar dos problemas relacionados se aplicarem também a sistemas de condicionamento de ar de pequeno porte, tais como: residências e veículos, o principal foco deste trabalho destina-se a locais com grande exposição de pessoas, em virtude da criticidade e do impacto causado. Porém, as medidas de manutenção recomendadas também devem ser aplicadas aos sistemas de menor dimensão.

\subsection{Principais poluentes, fontes e respectivos efeitos}

Os contaminantes presentes em sistemas condicionados, bem como em qualquer outro tipo de ambiente, podem ser classificados em:

- contaminantes químicos;

- contaminantes físicos,

- contaminantes biológicos. 
Para garantir o correto controle de uma fonte poluente, precisamos observar a concentração máxima admissível para permanência de 8 horas / dia e calcularmos a quantidade de ar externo necessário para sua diluição. A necessidade de diluição exige trazer grandes taxas de ar externo e, conseqüentemente, maiores gastos com energia. É mais razoável e econômico evitar a dispersão dos poluentes químicos, físicos ou biológicos, que adotar soluções corretivas drásticas e onerosas. A cultura do cheiro de limpeza, muito difundida pela mídia e, hoje, sedimentada na cultura popular brasileira, causa diversas manifestações alérgicas aos ocupantes de ambientes climatizados, sendo, na maioria das vezes, confundidas como manifestações alérgicas, oriundas da Síndrome do Edifício Doente, assim como os demais poluentes que comprometem os sistemas respiratórios, a visão, o sistema digestivo e até mesmo o sistema nervoso.

\subsubsection{Contaminantes químicos:}

A dosagem suportada pelo organismo é estabelecida pela relação entre a dose de um agente tóxico que penetrou no organismo e o grau de resposta deste para a eliminação. A quantidade total de contaminante, que penetra no sistema respiratório, será eliminada segundo sua propriedade seletiva de rejeição para vários materiais nele depositados. Para estabelecer, quantitativamente, uma relação dose-resposta, no local crítico, devemos estimar:

- quanto do agente é inicialmente depositado no sistema respiratório, 
- com que rapidez os agentes depositados são removidos pelo mecanismo de limpeza do trato respiratório e pulmões e

- qual a fração de agentes que atingem o local crítico dentro dos pulmões que alcançará outras partes do organismo e que danos poderá causar.

Estudos comprovam que determinados poluentes químicos trazem grandes conseqüências aos ocupantes dos ambientes, sendo sua presença indesejável, devido às dificuldades de eliminação pelo trato respiratório, ou ainda a afinidade que o poluente tenha por alguns tecidos, promovendo um processo de deposição cumultativa.

Assim os principais poluentes químicos, encontrados nos sistemas de ar condicionado, são: monóxido de carbono $(\mathrm{CO})$, dióxido de nitrogênio $\left(\mathrm{NO}_{2}\right)$, ozônio $\left(\mathrm{O}_{3}\right)$, dióxido de carbono $\left(\mathrm{CO}_{2}\right)$, óxidos de enxofre ( $\left.\mathrm{SOx}\right)$, compostos orgânicos voláteis (COV), formaldeídeos e produtos químicos diversos, utilizados em processos de limpeza e manutenção. A seguir, estão descritas as principais características de cada poluente, as principais fontes geradoras e os respectivos efeitos de curta e longa exposição.

Monóxido de Carbono: gás incolor, inodoro que evita a troca de oxigênio do pulmão com o fluxo sangüíneo.

Fontes: gases de combustão gerados no processo de queima de combustível, realizados em processos industriais, tais como, caldeiras e na descarga de escapamentos de automóveis. 
Efeitos de curto tempo de exposição: fadiga.

Efeitos de longo tempo de exposição: visão embaralhada, falta de concentração e de coordenação, dor de cabeça, dores articulares, coriza, náusea.

Dióxido de nitrogênio: gás incolor, inodoro, que irrita as mucosas e membranas.

Fontes: queima de gás de cozinha, fumo em ambientes condicionados.

Efeitos de curto tempo: irritação nos olhos, irritação no nariz, na garganta, co-fator para a infecção pulmonar.

Ozônio: gás incolor, inodoro que irrita as mucosas e membranas.

Fontes: motores elétricos e máquinas fotocopiadoras.

Efeitos de curto tempo: irritação nos olhos, nariz, garganta, indução de crises de asma.

Efeitos de longo tempo: redução da capacidade pulmonar.

Dióxido de carbono: gás incolor e inodoro.

Fontes: respiração, processos de queima de combustíveis.

Efeitos de curto tempo: dores articulares, letargia.

Efeitos de longo tempo: metahemoglobinemia.

\section{Óxidos de enxofre (SOx):}

Fontes: processos de queima de combustível que contenha enxofre em sua composição. 
Efeitos de curto tempo: irritação nos olhos, nariz, garganta, indução de crises de asma.

Efeitos de longo tempo: redução da capacidade pulmonar.

\section{Compostos Orgânicos Voláteis (COV):}

Fontes: solventes, contendo por exemplo: benzeno, tetracloreto de carbono, tolueno, xileno, tricloroetano, cera, mobiliário, materiais de revestimento, tintas, colas.

Efeitos de curto tempo: dores articulares, dor de cabeça, enxaquecas, vômitos.

Efeitos de longo tempo: câncer, leucopenia, danos ao sistema nervoso central.

Formaldeídeos: gás incolor irritante

Fontes: verniz de mobiliários, retardantes de chama, divisórias e aglomerados de madeira.

Efeitos de curto tempo: irritação nos olhos, garganta, náusea, dificuldades respiratórias, indução a crises de asma.

Efeitos de longo tempo: câncer.

Produtos químicos diversos utilizados em processo de limpeza e manutenção:

Fonte: tintas, solventes, verniz, produtos aerosóis, desinfetantes, sachês, anti-mofo, hipoclorito de sódio, ceras, produtos automotivos, odorizadores de ar, inseticidas.

Efeitos de curto tempo: irritação nos olhos, nariz, garganta e podem causar danos ao figado.

Efeitos de longo tempo: câncer, danos ao sistema nervoso central e ao sistema reprodutivo. 


\subsubsection{Contaminantes biológicos:}

Sempre que citamos os contaminantes biológicos, a cultura popular nos remete aos vírus e aos estados virais a exemplo das gripes. Porém, estes não se reproduzem em ambientes condicionados, pois, dependem do parasitismo celular para se reproduzirem, sendo sua forma mais comum de contágio, o contato direto com as pessoas.

Os fungos e as bactérias se reproduzem em qualquer ambiente que apresente meios favoráveis à nutrição e à reprodução destes organismos. A matéria particulada funciona num primeiro momento como um substrato ideal para a multiplicação microbiana, que, em condições favoráveis, se bipartem a cada vinte minutos, em média, multiplicando-se assim de modo assustador, aumentando a concentração de agentes biológicos nos ambientes.

Em um segundo momento, a matéria particulada vai atuar como elemento sinérgico no ecossistema biológico, através do aumento da umidade relativa nas superficies, aumentando o crescimento microbiano. Este fenômeno de aumento da umidade se dá através primeiro da tensão superficial, onde duas partículas próximas entre si absorvem água, aprisionando-a. Embora os seres humanos e a qualidade de vida desses elementos constituam o principal objetivo da ciência que estuda o controle de qualidade de ar de interiores, os seres humanos também liberam no seu ambiente de trabalho, bem como em seu domicílio e em todos os ambientes interiores, grande quantidade de material físico e biológico, tais como: pó, escama de pele, microorganismos, vírus, fungos, bactérias e líquidos corpóreos. 
Os poluentes biológicos encontram, na decoração dos ambientes, revestimentos de materiais fibrosos ou com superficie irregular, tecidos, tapetes e cortinas, aliados para sua retenção, manutenção e propagação, além de ótimos criatórios de artrópodes (ácaros). Outra fonte significativa de fungos, nos ambientes, são vasos com plantas cultivadas em terra, vasos de xaxim e pratos com água sob os vasos. O uso do entre-forro para retorno de ar é uma prática condenável, por ser um grande foco de acúmulo de pó, tendo ainda como agravante o fato de nunca receber a luz solar, não ter nenhuma ventilação externa com elevada umidade, tornando-se um excelente local para a proliferação de fungos e bactérias. O mesmo acontece em shafts de tubulações, ventilação de sanitários, que algumas vezes são utilizados como ponto de coleta das tomadas de ar externo do sistema de ar condicionado.

A seguir estão descritos alguns tipos de poluentes biológicos e os respectivos efeitos da exposição a estes microorganismos.

Fungos: Histoplasma sp, Aspergillus sp, Alternaria sp, Penicilium sp, Cladosporium $\mathrm{sp}$

Principais fontes: ambientes úmidos e demais fontes de multiplicação fúngica, como materiais porosos orgânicos úmidos, forros, paredes e isolamentos úmidos; ar externo, interior de condicionadores sem manutenção, vasos de terra com plantas.

Principais doenças transmitidas por fungos: histoplasmose, infecções, broncopneumonia alérgica, alveolite alérgica, toxicose, asma, alergias, rinite. 
Bactérias: Mycobacterium tuberculus, Bacillus sp, Pseudomonas aleuginosas.

Principais fontes: reservatórios com água estagnada, torres de resfriamento, bandejas de condensado, desumidificadores, umidificadores, serpentinas de condicionadores de ar e superficies úmidas e quentes.

Principais doenças transmitidas por bactérias: tuberculose, alveolite alérgica, infecções oportunistas, mucovisidose.

Protozoários: Acanthamoeba, Naeghleria.

Principais fontes: reservatórios de água contaminada, bandejas e umidifcadores de condicionadores sem manutenção.

Principais doenças transmitidas por protozoários: ceratite amebiana e encefalite.

Artrópodes: ácaros e baratas.

Principais fontes: poeira caseira.

Principais doenças transmitidas por artrópodos: asma, alergias.

\subsubsection{Contaminantes físicos:}

É nos contaminantes inertes que temos uma perigosa classe de materiais que não são biodegradáveis, como é o caso das fibras minerais, que não são eliminadas pelo organismo e podem causar pneumoconiose, fibrose pulmonar, além de aumentar a probabilidade do surgimento de células cancerígenas. 
Para o controle do material particulado presente, no fluxo de ar em ambientes interiores, não existe outra solução além de um adequado processo de filtragem, devendo esta ser criteriosamente avaliada para garantia da qualidade do ar. Abaixo estão apresentados os principais tipos de contaminantes físicos, alguns exemplos e os respectivos efeitos:

Fibras minerais: lã de vidro, lã de rocha e amianto.

Principais efeitos: silicose, pneumoconiose, fibrose pulmonar progressiva e câncer.

Poeiras de sílica: pedra sabão, talco, mica e cimento.

Principais efeitos: silicose, pneumoconiose e fibrose pulmonar progressiva.

Poeiras genéricas (origem vegetal): poeira atmosférica, fibras de algodão, fumaça de cigarro, celulose e pólen de plantas.

Principais efeitos: irritação nas mucosas nasais e garganta.

A contaminação dos ambientes, que traz como conseqüência os riscos à saúde humana, pode ser distribuída em quatro grandes grupos, de acordo com a sua origem:

Grupo 1 - Contaminação interior:

Concentração de formaldeído liberado por móveis, divisórias e carpetes, compostos orgânicos voláteis, agentes de limpeza, tabagismo, plantas, terra onde 
estão plantadas, águas nos vasos, ozônio resultante de motores elétricos, copiadoras, além da contaminação transportada para dentro do ambiente por pessoas.

Grupo 2 - Contaminação exterior:

Trazida ao ambiente interno, devido à necessidade de ventilação e renovação do ar interior pelo ar exterior. $O$ ar exterior, dependendo da sua fonte de captação e condição, pode apresentar teores significativos de monóxido de carbono, dióxido de carbono, dióxido de nitrogênio, ozônio, fumaças em geral e particulados.

Grupo 3 - Contaminação no sistema de ar condicionado propriamente dito:

O sistema de ar condicionado pode tornar-se, com o decorrer do tempo, uma importante fonte de contaminação, com foco em alguns componentes (que podem ser considerados pontos fracos): unidades de tratamento de ar, dutos, sistema de distribuição e sistema de renovação de ar.

Grupo 4 - Deficiências de um sistema global incorreto:

Incluem-se neste item as causas de qualidade de ar insatisfatória, provocadas por: insuficiência de ar exterior, má distribuição de ar, controle deficiente de temperatura e localização inadequada da tomada de ar exterior. 


\subsection{Principais problemas e riscos potenciais envolvidos com a contaminação de ambientes internos}

Um equipamento de refrigeração, isto é, um tipo de equipamento utilizado para a climatização de ambientes, independente do uso, é constituído basicamente de um módulo compressor, um módulo condensador, um módulo expansor e um módulo evaporador, completando, o ciclo frigorífico, conforme figura 1.

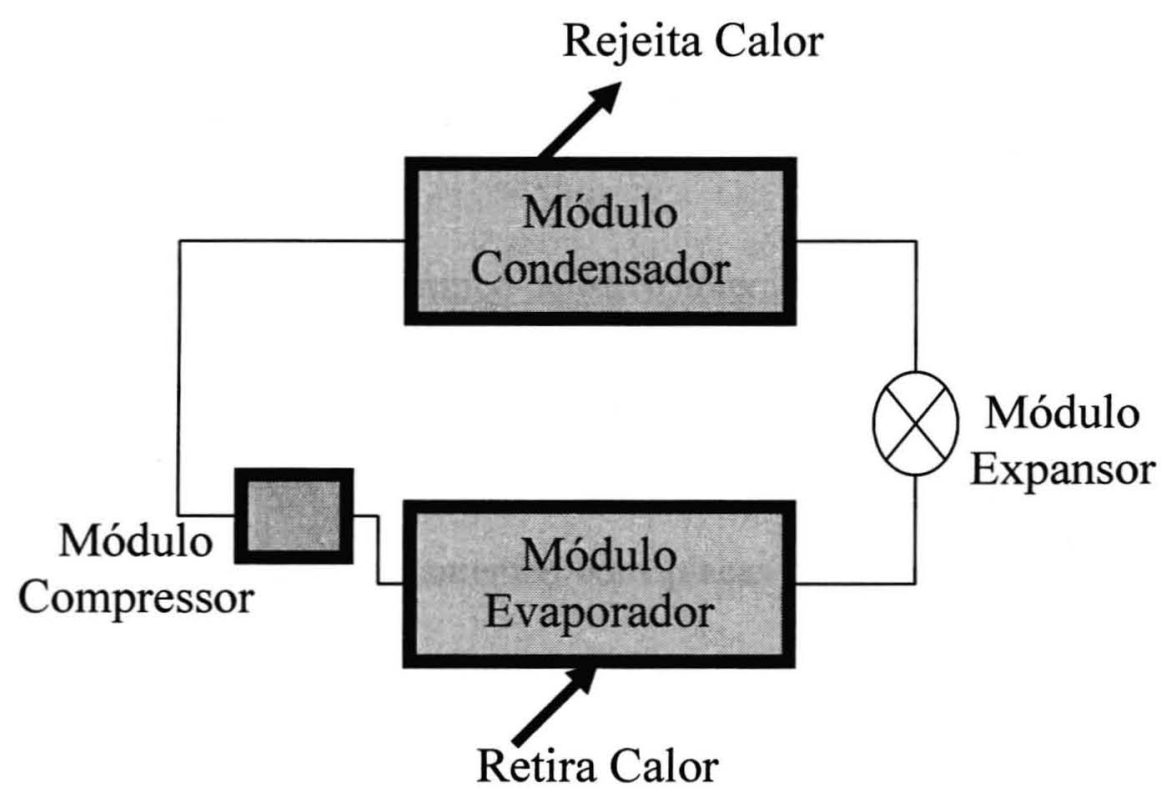

Figura 1: Ciclo Frigorífico

Demais acessórios são utilizados para garantir um melhor desempenho térmico e energético. Nos sistemas do tipo expansão direta, estes módulos são contidos em gabinetes metálicos ou gabinetes plásticos, providos de painéis removíveis para manutenção dos componentes internos. 
O módulo evaporador é o responsável pela troca de calor latente e sensível do ar através da serpentina de evaporação.

Além do sistema principal, os seguintes equipamentos são obrigatoriamente encontrados no processo de climatização de ambientes:

Gabinetes metálicos: os condicionadores tipo self-contained e fan-coil possuem painéis em chapas de aço dobradas e pintadas. Servem como revestimento e proteção do sistema principal. Exatamente por serem metálicos, podem apresentar oxidação, descascamento ou sobreposição de pintura, formando patamares irregulares, propícios para o acúmulo de pó.

Isolamento térmico-acústico interno dos painéis: tem como finalidade retardar a transferência de calor entre o interior e o exterior do equipamento, para evitar a condensação do vapor de água e o desperdício de energia. Equipamentos mais antigos possuem isolamentos com placas de lã de vidro. A manipulação dos painéis acaba retirando a resina protetora ou provocando a sua degradação física. A lã, quando degradada, pode além de liberar fibras minerais para os dutos e dissipá-las para o meio ambiente, permitir foco de material particulado, que é o meio propício para a proliferação de fungos e bactérias. A formação de bolores também pode aparecer em virtude da umidade do ar próximo à serpentina ou pelo transbordamento da bandeja de condensado com drenagem inadequada.

Serpentina evaporadora: é geralmente construída com tubos de cobre e aletas de alumínio com moldura em aço galvanizado. Os materiais sólidos que 
atravessam o filtro se compactam entre as aletas, provocando uma diminuição da vazão de ar insuflado no ambiente, maior consumo de energia e menor eficiência do equipamento.

Filtros de ar: elementos que têm a propriedade de filtrar o ar na entrada do módulo de evaporação. A principal função é a retenção do material particulado em suspensão no ar, proveniente do retorno do exterior ou da caixa de mistura. Quanto maior a eficiência da filtragem e melhor a manutenção periódica, maiores beneficios para a qualidade do ar interno.

Ventilador do evaporador: é o componente responsável pelo transporte do ar até o ambiente condicionado, pelo seu retorno e pela sucção do ar de renovação. Normalmente do tipo centrífugo, com acionamento indireto por polias e correias, o motor elétrico é local de grande concentração de material particulado. Pela sujidade do ventilador, pode-se confirmar a baixa eficiência do filtro e a necessidade do aumento do grau de filtragem.

Bandeja de condensado: é um dos maiores focos de cultura de bactérias e fungos. O material de fabricação, o formato e a declividade da bandeja também interferem na qualidade. Possuem quatro condições básicas para a proliferação de bioaerosóis:

- reservatório adequado,

- fonte de nutrientes, 
- amplificação e crescimento dos microorganismos (possíveis por haver água estagnada, nutrientes e temperatura adequada) e

- disseminação e aerosolização da água contendo microorganismos (efetuada pela passagem do ar pela água da bandeja).

A presença do dreno com sifão, contendo selo hídrico superior à pressão do ventilador, é indispensável para garantir o escoamento da água, evitando assim a aspiração do ar pelo tubo de drenagem.

O sistema de ar condicionado, sendo originalmente "inerte", pode inclusive tornar-se, com o decorrer do tempo, uma fonte propícia à contaminação, com destaque para os seguintes pontos, além daqueles acima mencionados:

- unidades de tratamento de ar: serpentinas de resfriamento e condensação, onde se podem localizar algas, fungos e poeiras como nas bandejas de condensado,

- dutos: tubulação de distribuição do ar a partir das máquinas de resfriamento, apresentam elevado grau de sujeira desde o processo de instalação,

- distribuição de ar: a introdução de quantidade adequada de ar em um ambiente, com taxas de ar exterior apropriadas, não é a garantia de que a efetividade da ventilação seja conseguida, pois pode haver curtos-circuitos entre o insuflamento e o retorno, divisórias que 
impeçam circulação apropriada do ar, difusores de ar não adequados, ocasionando uma velocidade acima dos valores recomendados $(0,15 \mathrm{~m} / \mathrm{s})$ na zona de ocupação e

- renovação de ar :pode ser um ponto fraco em alguns sistemas. Normalmente, é calculada a vazão por sala e considerada como ar a quantidade da tomada de ar exterior, a soma das necessidades individuais por sala, podendo provocar, por exemplo, numa sala interior que tenha um valor baixo de ar insuflado e no entanto seja um auditório com muitas pessoas.

As distorções das variáveis básicas necessárias para o controle operacional dos sistemas de ambientes climatizados provocam:

- o desconforto térmico, causando danos a produtos e equipamentos,

- o desequilíbrio ambiental, ocasionando vários quadros clínicos e prevalecendo as seguintes sintomatologias: dores de cabeça, irritação nos olhos, na garganta e no nariz, tosse seca, dermatites, dores articulares, fadiga, sonolência, dificuldade de concentração e sensibilidade a odores, podendo favorecer o crescimento dos agentes microbiológicos.

A sintomatologia no processo de agressão ao ser humano, isto é, a relação entre a concentração de um elemento no ar e os efeitos provocados no ser humano, depende diretamente de alguns fatores que podem variar de acordo com o 
tipo de poluente. Para isso o conhecimento das seguintes informações faz-se necessário:

- concentrações médias dos poluentes no meio ambiente;

- níveis de absorção pelo organismo em função da exposição durante períodos curtos e longos;

- distribuição do tamanho de partículas (para os casos de material particulado);

- picos de exposição;

- freqüência dos picos de exposição,

- lapso do tempo entre a análise e o estudo dos efeitos sobre a saúde e

- resposta individual do agredido.

Considerando os fatores citados acima, os efeitos para a saúde dos seres humanos expostos a ambientes fechados, podem ser apresentados em cinco grupos principais de riscos:

- reações de hipersensibilidade não específica;

- efeitos crônicos irreversíveis;

- sintomatologias gerais reversíveis,

- reações inflamatórias e

- sensibilidade incluindo odores, sensação de irritação, mucosas e pele secas. 
Além de existir um consenso geral, em todos os estudos realizados quanto à relação entre o crescimento microbiano e reações, como: congestão e irritação nasal e de garganta, tosse seca, problemas dermatológicos, irritação dos olhos, dores de cabeça e fadiga, os dados epidemiológicos existentes confirmam a ação das condições ambientais sobre a saúde dos ocupantes.

As sintomatologias são características de inflamações não específicas das vias respiratórias e compreendem quatro categorias de doenças:

1. Pneumoniatóxica: manifesta-se através de sintomas similares aos da gripe, que regridem, quando os queixosos se afastam do local. Esporos microbianos e endotoxinas são normalmente os agentes causais. Como exemplo, pode-se mencionar a pneumonia de hipersensibilidade que é uma doença respiratória, causada por uma reação do sistema imunológico a uma variedade de poeiras orgânicas comuns em ambientes de trabalho e residências. Diversos microorganismos identificados, em sistemas de ventilação, ar condicionado e umidificação, como protozoários, bactérias e fungos foram associados a esta doença.

2. Inflamação das vias respiratórias: caracteriza-se por irritação das vias, congestão nasal e coriza, tosse seca, geralmente acompanhadas de dores de cabeça, fadiga e dores articulares. Não se trata de reação alérgica e pode ser causada por diversos agentes ambientais, incluindo as endotoxinas. 
3. Alveolite alérgica: doença inflamatória que pode resultar em fibrose pulmonar, causada pela exposição prolongada à poeira orgânica. Os agentes causais são fungos, porém, raros casos foram descritos em ambientes fechados.

4. Asma, rinite e conjuntivite: são os resultados da exposição crônica a um determinado alérgeno. Os agentes causais são os diversos alérgenos presentes nos ambientes fechados.

Muitos dos poluentes relevantes, em ambientes fechados, já são conhecidos do ponto de vista toxicológico e seus efeitos sobre a saúde na literatura, porém, a maioria se refere a condições extremas de exposição, portanto, dificilmente, aplicável ao caso dos ambientes fechados. Uma situação idealizada seria ter a avaliação toxicológica dos riscos sobre a saúde da exposição a uma mistura de diversos poluentes químicos em pequenas doses, baseada de forma balanceada na relação dose / efeito de cada elemento químico, porém, esses dados não estão disponíveis até o momento.

Apesar desta dificuldade em se encontrar relação direta de doenças relacionadas com poluentes individualizados e suas respectivas concentrações, levantamentos bibliográficos e relatos técnicos confirmam casos, tais como:

- surto de febre e sintomas de gripe, descritos em uma fábrica cujos umidificadores estavam contaminados com pseudomonas. 
- estudos apontaram níveis elevados de endotoxina (concentrações cinco vezes maior do que quando comparados com prédios sem problemas), em prédios em que as pessoas apresentavam problemas respiratórios.

- infecção hospitalar ataca em média 13 a cada 100 pacientes internados, sendo que $10 \%$ deste total é responsabilidade de ar interno contaminado por fungos e bactérias que se multiplicam e disseminam pelo sistema de ar condicionado ou, simplesmente, pelo ar do ambiente hospitalar.

- um hospital paulistano passou por um desses surtos em ambiente de terapia intensiva, registrando mais de 100 casos de infecções em uma mesma semana.

- existem vários surtos relacionados com o fungo Aspergillus que causa pneumonia e sinusite. Este fungo está associado a reformas mal planejadas, em que temos liberação dos poros desses fungos e contaminação de pacientes.

- a inalação de matéria particulada em suspensão das mais variadas origens, tem demonstrado estreita correlação com problemas respiratórios e outras sintomatologias (Nicholls, P.J., 1994). 


\subsection{Os requisitos legais aplicáveis aos sistemas}

A Constituição da República traz em seu artigo 225 (1.988) a tutela ao meio ambiente, reconhecendo-o como "bem de uso comum do povo e essencial à sadia qualidade de vida, impondo-se ao Poder Público e à coletividade o dever de defendê-lo e preservá-lo para as presentes e futuras gerações".

No artigo 23 inciso IV, define como competência de todos os entes federativos para a proteção do meio ambiente e combate à poluição, em qualquer de suas formas, como pode ser confirmado na redação abaixo:

“Art 23: É competência comum da União, dos Estados, do Distrito Federal e dos Municípios:

III - proteger os documentos, as obras e outros bens de valor histórico, artístico e cultural, os monumentos, as paisagens naturais notáveis e os sítios arqueológicos;

IV - impedir a invasão, a destruição e a descaracterização de obras de arte e de outros bens de valor histórico, artístico e cultural;

VI - proteger o meio ambiente e combater a poluição em qualquer de suas formas;

VII - preservar as florestas, a fauna e a flora."

Percebe-se a determinação clara do legislador, quanto às áreas de competências a serem exercidas pela União, Estados, Distrito Federal e os Municípios. 
Reforça ainda os níveis e a possibilidade da existência de requisitos diferenciados, para atender necessidades específicas dos estados e municípios:

“Artigo 24: Parágrafo Segundo: A competência da União para legislar sobre as normas gerais não exclui a competência suplementar dos estados."

“Artigo 30: Compete aos municípios:

II- Suplementar a legislação federal e estadual no que couber."

Conclui-se então a definição de duas ordens de competência bastante distintas: a implementadora sob a competência de todos os entes da federação e a legislativa, cabendo à União estabelecer normas gerais, podendo os demais suplementá-las e as competências concorrentes ,isto é, para atender as peculiaridades, os estados e municípios poderão editar leis próprias, desde que inexista lei federal disciplinadora. Portanto, entende-se que os estados e municípios possuem poder suplementar.

No âmbito federal, a Lei 6938 de 31 de agosto de 1.981 estabeleceu as bases para a Política Nacional de Meio Ambiente, dispondo sobre a ação integrada dos órgãos que compõem o Sistema Nacional do Meio Ambiente - SISNAMA. Em âmbito nacional, fica estabelecido um conjunto articulado de órgãos, entidades e regras que envolve a União, os Estados e os Municípios, com vistas à proteção da qualidade ambiental. Cabe aos integrantes do SISNAMA promover a adequada estrutura administrativa, para desenvolver com aptidão, as funções relacionadas com a preservação ambiental. O papel dos municípios, como entes federativos autônomos e, nesta qualidade, integrantes do SISNAMA, é destacado, pois a este incumbe organizar-se, de forma a assumir a competência inerente à gestão ambiental das 
questões locais. Portanto, cabe aos municípios, responsabilizar-se pela avaliação e pelo estabelecimento de normas, critérios e padrões relativos ao controle e manutenção da qualidade ambiental em seu território.

Com referência ao controle ambiental da poluição atmosférica, as seguintes normas podem ser destacadas:

- $\quad$ Resolução CONAMA 05/89 que instituiu o PRONAR: Programa Nacional de Controle da Qualidade do Ar, visando à adoção de medidas para a melhoria da qualidade do ar, em todo o território nacional;

- $\quad$ Resolução CONAMA 03/90 que fixou os padrões de qualidade do ar e definiu os parâmetros para os episódios agudos de poluição atmosférica;

- Resolução CONAMA 08/90: estabeleceu limites máximos de emissão de poluentes do ar para processos de combustão externa com potenciais nominais totais até $70 \mathrm{MW}$ e superiores, realizados em: caldeiras, geradores de vapor, centrais para a geração de energia elétrica, fornos, fornalhas, estufas e secadores para geração e uso de energia térmica, incineradores e gaseificadores;

- Resoluções CONAMA 07 e 08/93 que definiram as diretrizes básicas e os padrões de emissões mínimos para veículos em uso,

- $\quad$ Lei $8723 / 93$ que criou procedimentos para as inspeções periódicas de veículos bem como sua fiscalização e 
- $\quad$ Lei Municipal de São Paulo 11.733/95 que instituiu o Programa de Inspeção e Manutenção de Veículos, para a aferição da frota cadastrada e buscou promover a substituição dos ônibus movidos a diesel pelo gás.

Com relação ao controle da qualidade de ar de interiores, a legislação apresentava-se de forma esparsa até a edição da Portaria 3.523 de 28 de agosto de 1.998, por iniciativa do Ministério da Saúde.

Os principais motivos da edição desta portaria estão relacionados à identificação dos problemas de saúde, provocados pela síndrome dos edifícios doentes (condições do ambiente interno) e pela repercussão causada com a morte do então Ministro das Comunicações, Sérgio Motta, em virtude de uma infecção pulmonar. Uma das hipóteses veiculadas foi a ação de microorganismos encontrados no sistema de climatização do seu gabinete, que posteriormente foi descartada.

A Portaria 3.523 estabeleceu como principais itens os Artigos transcritos abaixo:

“Artigo 1: Aprovar o Regulamento Técnico contendo as medidas básicas referentes aos procedimentos de verificação visual dos procedimentos de limpeza, remoção de sujidades por métodos físicos de manutenção do estado de integridade e eficiência de todos componentes dos sistemas de climatização, para garantir a Qualidade do Ar Interiores e prevenção de riscos à saúde dos ocupantes de ambientes climatizados."

“Artigo 2: Determinar que serão objeto de Regulamento Técnico a ser elaborado por este Ministério, medidas específicas referentes a padrões de qualidade do ar em ambientes climatizados, no que diz respeito à definição de parâmetros 
físicos e composição química do ar de interiores, a identificação dos poluentes de natureza fisica, química e biológica, suas tolerâncias e métodos de controle, bem como pré-requisitos de projetos de instalação e execução de sistemas de climatização."

"Artigo 5: Todos os sistemas de climatização devem estar em condições adequadas de limpeza, manutenção, operação e controle..."

Estabeleceu a obrigatoriedade da implantação de um Plano de Manutenção, Operação e Controle - PMOC - sob a responsabilidade de um técnico (Artigo 6) habilitado com as principais atribuições:

a) Descrever as atividades a serem desenvolvidas, periodicidades e as recomendações e situações de falha do equipamento e de emergência;

b) Garantir a aplicação do PMOC por intermédio da execução contínua direta ou indireta deste serviço,

c) Manter disponível o registro da execução dos procedimentos estabelecidos $\mathrm{e}$

d) Divulgar os procedimentos e resultados das atividades de manutenção, operação e controle aos ocupantes.

"Artigo 7: O PMOC do sistema de climatização deve estar coerente com a legislação de Segurança e Medicina do Trabalho. Os procedimentos de manutenção, operação e controle dos sistema de climatização e limpeza dos ambientes climatizados não devem trazer riscos à saúde dos trabalhadores que os executam, nem aos ocupantes dos ambientes climatizados."

A referida portaria apresenta ainda, em seus anexos 1 e 2, modelos de formulários com os itens a serem checados e que serão detalhados no item 1.4. 
Ainda como evolução dos requisitos legais vinculados à prevenção da poluição ambiental e conforme definido no Artigo 2 da Portaria 3.523, a Agência Nacional de Vigilância Sanitária publicou em 24 de outubro de 2.000 a Resolução da Agência Nacional de Vigilância Sanitária nº 176 e, mais recentemente, a Resolução $\mathrm{RE} \mathrm{n}^{\mathrm{o}} 09$ de 16 de janeiro de 2.003 que praticamente substituiu a anterior e estabeleceu os padrões referenciais de qualidade do ar interior. Tais padrões definem os critérios microbiológicos, químicos e físicos.

Para a contaminação microbiológica foi definido como valor máximo permitido 750 ufc $/ \mathrm{m} 3$ de fungos, além de 1,5 para a relação $\mathrm{I} / \mathrm{E}$, sendo I a quantidade de fungos no ambiente interior e $\mathrm{E}$ a quantidade no ambiente exterior, sendo também inaceitável a presença de fungos patogênicos ou toxigênicos.

Para a contaminação química foram definidos:

a) $1000 \mathrm{ppm}$ de dióxido de carbono, como indicador de renovação de ar externo, recomendado para o conforto e bem- estar,

b) $\quad 80 \mathrm{mg} / \mathrm{m} 3$ de aerodispersóides totais no ar, como indicador de pureza do ar e limpeza do ambiente climatizado.

Para os parâmetros físicos estão definidos como valores recomendados: 
a) Temperatura: durante o verão a temperatura interna deve variar entre 23 e $26^{\circ} \mathrm{C}$, com exceção de ambientes de artes que devem operar entre 21 e $23^{\circ} \mathrm{C}$. Para condições de inverno a faixa recomendada fica entre 20 e $22^{\circ} \mathrm{C}$.

b) Umidade relativa: durante o verão a faixa de variação aceita é entre 40 e $65 \%$, enquanto que no inverno entre 35 e $65 \%$. Para ambientes de arte os valores são mais restritivos entre 40 e $55 \%$.

c) Velocidade do ar: no nível do piso a velocidade deve variar entre $0,025 \mathrm{~m} / \mathrm{s}$ a $0,25 \mathrm{~m} / \mathrm{s}$.

d) Taxa de renovação do ar: mínimo de $27 \mathrm{~m}^{3} /$ hora / pessoa, excetuando, em casos específicos, como lojas, centros comerciais, bancos e outros, onde a taxa mínima é de $17 \mathrm{~m}^{3} /$ hora / pessoa.

e) Grau de pureza: deve ser obtido, através da utilização, no mínimo, de filtros classe G-3, nos condicionadores dos sistemas.

Adicionalmente aos critérios técnicos e parâmetros quantitativos acima apresentados, a Resolução $\mathrm{n}^{\circ} 09$ apresenta as normas técnicas a serem seguidas para a coleta de amostras e a execução dos testes analíticos, com o intuito de minimizar os riscos de falha nos procedimentos e, conseqüentemente, garantir maior confiabilidade nos resultados obtidos. 
Esta resolução apresenta ainda recomendações direcionadas para as atividades de manutenção, de acordo com o tipo de poluente seja, ele químico, físico ou biológico, encontrado nos monitoramentos efetuados:

\section{Contaminantes Biológicos}

Bactérias: realizar limpeza e conservação das torres de resfriamento, higienizar os reservatórios e bandejas de condensado ou manter tratamento contínuo para eliminar as fontes, as infiltrações e higienizar as superficies. A legionella habita principalmente ambientes climatizados, sendo encontrada em sistemas de ar condicionado ou nos sistemas de aquecimento central.

Fungos: corrigir a umidade ambiental, manter sob controle rígido vazamentos, infiltrações e condensação de água, higienizar os ambientes e componentes do sistema de climatização ou manter tratamento contínuo para eliminar as fontes e materiais porosos contaminados, eliminar ou restringir vasos de plantas com cultivo em terra, ou substituir pelo cultivo em água, utilizar filtros apropriados na renovação do ar externo.

Protozoários: higienizar o reservatório ou manter tratamento contínuo para eliminar as fontes.

Vírus: adequar o número de ocupantes por $\mathrm{m}^{2}$ de área com aumento da renovação do ar, evitar a presença de pessoas infectadas nos ambientes climatizados. 
Algas: higienizar os reservatórios e bandejas de condensado ou manter tratamento contínuo para eliminar as fontes.

Artrópodes: higienizar superficies fixas e mobiliário, especialmente os revestidos com tecidos e tapetes; restringir ou eliminar o uso desses revestimentos.

\section{Contaminantes Químicos}

CO (monóxido de carbono): manter a captação de ar exterior com baixa concentração de poluentes, restringir as fontes de combustão, manter a exaustão em áreas onde ocorre a combustão, eliminar a infiltração do monóxido de carbono provenientes de fontes externas e restringir o tabagismo em áreas fechadas.

$\mathrm{CO}_{2}$ (dióxido de carbono): aumentar a renovação do ar externo, restringir as fontes de combustão e o tabagismo em áreas fechadas, eliminar a infiltração de fontes externas.

$\mathrm{NO}_{2}$ (dióxido de nitrogênio): restringir as fontes de combustão, manter a exaustão em áreas em que ocorre a combustão, impedir a infiltração de $\mathrm{NO}_{2}$ provenientes de fontes externas, restringir o tabagismo em áreas fechadas.

$\mathrm{O}_{3}$ (ozônio): adotar medidas específicas para reduzir a contaminação dos ambientes interiores, com exaustão do ambiente ou enclausuramento em locais 
exclusivos para os equipamentos que apresentem grande capacidade de produção de ozônio.

Formaldeídeos: selecionar os materiais de construção, acabamento e mobiliário que possuam ou emitam menos formaldeídeos, usar produtos domissanitários que não contenham formaldeídeos.

Fumo de tabaco: aumentar a quantidade de ar externo admitido para renovação e / ou exaustão dos poluentes, restringir o tabagismo em áreas fechadas.

COV (compostos orgânicos voláteis): selecionar os materiais de construção, acabamento, mobiliário, usar produtos de limpeza e domissanitários que não contenham COV ou que não apresentem alta taxa de volatilização e toxicidade.

COSV (compostos orgânicos semi-voláteis): eliminar a contaminação por fontes pesticidas, inseticidas e a queima de combustíveis; manter a captação de ar exterior afastada de poluentes.

\section{Contaminantes Físicos}

Material particulado: manter filtragem de acordo com as normas técnicas vigentes; evitar isolamento termo-acústico que possa emitir fibras minerais orgânicas ou sintéticas para o ambiente climatizado; reduzir fontes internas e externas; higienizar superfícies fixas e mobiliários sem uso de vassouras, escovas ou 
espanadores; selecionar os materiais de construção e acabamento com porosidade, adotar medidas específicas para reduzir a contaminação dos ambientes interiores e restringir o tabagismo.

\subsection{A manutenção como forma de prevenção dos riscos}

Para que os valores limites estabelecidos pela legislação (Resolução ${ }^{0}$ 176 e Resolução $\mathrm{n}^{0}$ 09) possam ser obtidos faz-se necessária a implementação de processos de manutenção eficientes e alinhados com o Plano de Manutenção, Operação e Controle, definido na portaria do Ministério da Saúde 3.523.

As atividades de manutenção podem ser definidas como o conjunto de ações ou medidas que permitem conservar ou restabelecer um sistema em seu estado de funcionamento. Têm como principal objetivo manter a integridade física e funcional dos equipamentos, otimizar os recursos, permitir a redução dos gastos e, especificamente, para sistemas de ar condicionado, garantir a qualidade do ar com o controle contínuo das fontes de poluentes.

A manutenção preventiva é a manutenção efetuada em intervalos predeterminados ou de acordo com critérios prescritos, destinada a reduzir a probabilidade de falhas ou degradação de um item. Quando feita com qualidade e precisão, resolve cerca de $80 \%$ dos problemas, deixando $20 \%$ das ocorrências para a manutenção corretiva, que cuidará dos defeitos inevitáveis, que acontecem por acaso como, por exemplo, uma parada não esperada. Mesmo em situações não planejadas, a equipe que trabalha com a preventiva tem mais facilidade para encontrar a solução. 
A melhor maneira de justificar a manutenção preventiva, principalmente, quando se fala em custos, é avaliar as despesas com energia elétrica.

No caso de ar condicionado, uma ação preventiva bem feita economiza até $30 \%$ do valor total da manutenção. Em um edifício de escritório, o consumo de energia elétrica para o sistema de ar condicionado é de 60 a $70 \%$ e em um shopping 35 a $45 \%$. O ar condicionado é o maior consumidor individual, e, quando se fala em $30 \%$ de melhoria de eficiência e de redução de gastos, há uma diminuição considerável na conta de energia elétrica.

A seguir estão listadas as principais medidas de manutenção preventivas recomendadas para evitar possíveis contaminações ambientais. Estão distribuídas em quatro grupos apresentados, de forma detalhada, no final do item 1.2:

$\begin{array}{ll}\text { Grupo } 1 & \text { - Contaminação interior } \\ \text { Grupo } 2 & \text { - Contaminação exterior } \\ \text { Grupo } 3 & \text { - Contaminação no próprio sistema de ar condicionado } \\ \text { Grupo } 4 & \text { - Deficiências de um sistema global incorreto }\end{array}$

Para o Grupo I, a principal medida preventiva é a eliminação das fontes ou exaustões localizadas e a manutenção do sistema de ventilação em níveis adequados.

Para o Grupo II, os requisitos estão relacionados à captação de ar exterior, que para ser adequada, deve ser composta por venezianas, telas, filtros (que podem até ser de carvão ativado, caso o ar exterior não atenda às condições necessárias de pureza), para evitar que a contaminação exterior provoque 
complicações no ambiente interior e, conseqüentemente, no sistema de ar climatizado.

Para o Grupo III, as medidas preventivas são apresentadas de acordo com a característica de cada um dos equipamentos integrantes do sistema de ar condicionado e de distribuição do ar.

Para as unidades de tratamento de ar, recomenda-se:

- recobrimento do isolamento com chapas galvanizadas, alumínio ou aço inox, dependendo da aplicação de biocida,

- pintura interna na cor branca, epóxi, sendo as unidades providas de visores que permitam inspeção visual e

- unidades providas de iluminação interna com grau de proteção adequado contra jatos de água.

As bandejas de recolhimento de condensados devem, obrigatoriamente, ser construídas em aço inoxidável, com fundo inclinado e ligação de esgoto em seu ponto mais baixo. A manutenção recomendada é a limpeza mensal, enquanto que, semestralmente, deverá ser verificada a presença de pontos de oxidação e corrosão, aplicando pintura resistente à água, ou elastômero, tornando a superfície lisa e livre de deformações. Também deve-se aplicar sistema contínuo de tratabilidade da água contida na bandeja de condensado.

O sifão, ponto de escoamento da água, deve ter dimensão mínima de quatro polegadas de coluna de água para atender às altas pressões.

As serpentinas devem ser dimensionadas com no máximo seis linhas e dez aletas por polegada, de modo a facilitar o processo de limpeza, pois, quanto 
maior o número de linhas e aletas maior a dificuldade de uma limpeza adequada. A velocidade de arraste da água deve ser limitada em $2,75 \mathrm{~m} / \mathrm{s}$.

Os ventiladores devem ser de carcaça desmontável, facilitando a limpeza interna dos mesmos.

A umidificação deve ser feita por vapor limpo e seco com tubo dispersor antes do estágio final de filtragem, devendo esta ser sempre feita em dois estágios com a seleção dos filtros, de acordo com as características dos possíveis contaminantes presentes no sistema.

Os dutos devem possuir superficie interna lisa com limites de estanqueidade. A cada 15 metros deve haver portas de inspeção para serem utilizadas no processo de limpeza, com ligações flexíveis de no máximo 2,0 metros de comprimento com cuidados especiais na montagem quanto ao acúmulo de detritos, dampers de regulagem com aletas aerodinâmicas para evitar acúmulo de detritos, sempre com portas de inspeção.

As grelhas e os difusores devem ser elementos facilmente desmontáveis para permitir inspeções, limpeza e desinfecção, do tipo de alta indução, permitindo rápida equalização da temperatura e velocidades na zona de ocupação inferiores a $0,15 \mathrm{~m} / \mathrm{s}$.

Os filtros de ar (tanto os descartáveis quanto os reutilizáveis) necessitam de verificação periódica, definindo as freqüências de troca ou limpeza. Para os reutilizáveis a recomendação é mensal, porém podem existir locais que, devido às concentrações de contaminantes, a freqüência passe a ser semanal. Os descartáveis, instalados em locais de baixa concentração de poluentes, suportam um período de até três meses. 
Para a renovação de ar, deve ser feito cálculo rigoroso, garantindo que o percentual recomendado por pessoa seja sempre atingido.

Adicionalmente às ações de manutenção específicas para cada um dos equipamentos integrantes do sistema de condicionamento de ar, o procedimento de higienização deve ser aplicado a todos estes. A casa de máquinas também requer cuidados criteriosos durante as atividades de manutenção, principalmente, se ela estiver funcionando como caixa de mistura. Deve-se observar características dos forros, pinturas, drenos, esgotos, escotilhas de retorno de ar, além da própria higienização da mesma.

Os produtos químicos, utilizados para a higienização de ambientes interiores, devem atender a algumas premissas básicas: registro no Ministério da Saúde, não conter substâncias químicas consideradas poluentes de interiores, como cloro, formaldeído ou acetaldeídeo, apresentar comprovação de baixa irritabilidade e não devem possuir aroma, mesmo os utilizados em áreas de sanitários.

GrupoIV: projeto adequado ou reprojeto. As modificações que podem ter sido introduzidas após a execução do projeto original também comprometem o funcionamento adequado do sistema de ar condicionado.

As medidas de prevenção também podem ser agrupadas de acordo com o tipo de poluente predominante, garantindo também efetividade e redução das concentrações dos respectivos poluentes. 
Medidas para a redução de contaminantes químicos, biológicos e

físicos

\section{Contaminantes Químicos}

Monóxido de Carbono: eliminar ou restringir fontes de combustão, instalação de exaustão em áreas onde ocorre combustão, impedir a infiltração de monóxido de carbono proveniente, por exemplo, de fontes externas como garagens.

Dióxido de Carbono: Aumentar a taxa de renovação ou exaustão de ar.

Dióxido de nitrogênio: eliminar ou restringir fontes de combustão, instalação de exaustão em áreas onde ocorre combustão, impedir a infiltração de monóxido de carbono proveniente, por exemplo, de fontes externas como garagens.

Formaldeídeos: melhorar a seleção do material utilizado para a construção, acabamento e mobiliário de baixa emissão, usar produtos domissanitários que não contenham formaldeídeos.

Ozônio: reduzir fontes com a melhora das práticas de higienização e eliminar a contaminação do ar interior por máquinas copiadoras e impressoras a laser. 


\section{Contaminantes Biológicos}

Bactérias: realizar a limpeza e a conservação das torres de resfriamento, hgienizar os reservatórios e bandejas de condensado ou manter tratamento contínuo para eliminar as fontes, as infiltrações e higienizar as superficies.

Fungos: corrigir a umidade ambiental, manter sob controle rígido os vazamentos, infiltrações e condensação de água, higienizar os ambientes e componentes do sistema de climatização ou manter tratamento contínuo para eliminar as fontes e os materiais porosos contaminados, eliminar ou restringir vasos de plantas com cultivo de terra, ou substituir pelo cultivo com água.

Protozoários: higienizar o reservatório ou manter tratamento contínuo para eliminar as fontes.

Artrópodes: higienizar as superficies fixas e mobiliários, especialmente os revestidos com tecidos e tapetes; restringir ou eliminar o uso desses revestimentos.

\section{Contaminantes Físicos}

Partículas em suspensão: redução de fontes com a melhora das práticas de higienização. Reduzir a contaminação do ar interior por máquinas copiadoras, impressoras a laser. 


\section{OBJETIVOS}

Frente às evidências que comprovam a existência de doenças originárias da contaminação do ar interior, o propósito do presente trabalho é avaliar a eficácia das técnicas de manutenção, comumente empregadas através da análise de resultados e de conhecimento dos efeitos mais comuns, provocados no ambiente interior, pela ineficiência das ações de manutenção.

Dentre estas evidências, que incluem aquelas apresentadas na introdução deste trabalho, deve-se ressaltar a freqüente necessidade gerada pela preocupação com a qualidade do ar respirado em ambientes interiores climatizados, o que leva os responsáveis pelas organizações a avaliar as possíveis contaminações através da análise das condições microbiológicas do ar ambiental.

\subsection{Objetivos Específicos}

O propósito principal do trabalho está subdividido nos tópicos elencados a seguir:

- Apresentação de um breve histórico e da evolução de conceitos relacionados às doenças originárias em sistemas de ar condicionado;

- Realização de um levantamento atualizado da legislação que estabelece os requisitos legais referente ao tema; 
- Identificação dos principais contaminantes presentes em ambientes climatizados, suas origens e seus respectivos efeitos negativos para a saúde humana;

- Descrição do funcionamento dos sistemas de ar condicionado e as técnicas de manutenção freqüentemente utilizadas;

- Descrição e análise de resultados disponíveis na literatura vinculados a ocorrências adversas em sistemas de ar condiconado;

- Aplicação de uma programação de coleta de amostras em escala real e comparação com os requisitos legais vigentes,

- Levantamento e descrição das técnicas de manutenção comumente aplicadas em sistemas de ar condicionado e

- Análise crítica dos resultados obtidos, identificação dos possíveis pontos críticos do processo, e recomendação, se necessário, de ferramentas prevencionistas a serem aplicadas nos sistemas de ambientes climatizados.

Para que objetivos acima apresentados possam ser atingidos, serão utilizadas diversas metodologias, que serão abaixo descritas. 


\section{METODOLOGIA}

O objeto do presente estudo é constituído pelo levantamento bibliográfico de trabalhos científicos disponíveis em revistas técnicas especializadas nos últimos dez anos.

O período estipulado justifica-se frente ao baixo número de publicações existentes, vinculando a ocorrência de doenças originárias em sistemas com ambientes climatizados. Além disso, a seleção dos trabalhos foi baseada também na apresentação de evidências para a demonstração da eficácia das ações de manutenção como forma de prevenção das doenças.

Para o primeiro caso, o estudo apresentará como resultado os principais contaminantes existentes nos sistemas de ambientes climatizados, suas fontes mais prováveis, e os respectivos efeitos de cada um, além de referências sobre ocorrências das doenças mais comuns nas condições definidas por este trabalho.

Para o segundo caso, serão apresentados dados técnicos e resultados numéricos, fruto de pesquisas realizadas em situações distintas, considerando o ambiente, o tipo de sistema de climatização, o número de pessoas expostas. A discussão dos resultados está baseada na avaliação da eficácia das campanhas de manutenção e higienização dos sistemas selecionados, através da comparação direta dos valores coletados antes e depois das atividades operacionais de controle, direcionadas para este fim.

Além dos resultados obtidos na bibliografia, e para fornecer maior embasamento para atingir os objetivos estabelecidos neste trabalho, foi selecionado 
um caso piloto para a realização de coletas de amostras nos sistemas de ar condicionado, paralelamente, com a comparação dos valores obtidos com aqueles definidos pela legislação aplicável, apresentada na introdução deste.

Para a seleção deste caso, considerou-se uma série de condições favoráveis para a realização do estudo no que diz respeito à coleta de amostras, em função da existência prévia de um programa de prevenção de riscos ocupacionais, não causando elevação de custos ou desvios de procedimentos e padrões existentes. Soma-se a isso a existência de pré-requisitos mandatórios para a tipologia da indústria, com relação à concentração de poluentes nos locais de fabricação e os riscos existentes de contaminação do produto.

Apesar disso, os pontos selecionados não ficaram restritos apenas aos locais de fabricação, uma vez que a legislação não estabelece os locais, mas simplesmente o número de pontos a serem amostrados em virtude da dimensão da área climatizada. Sua escolha foi baseada nas áreas críticas em função dos riscos de exposição (incluindo áreas críticas, como restaurante, serviço médico e áreas administrativas).

Para o caso piloto, foi realizada uma campanha considerando três análises no período de um ano, quantidade tida como suficiente para estudar a eficácia das ações de manutenção, bem como período suficientemente extenso para o crescimento e proliferação de microorganismos nos sistemas de ar condicionado que podem ocasionar as doenças.

A metodologia de coleta e execução dos testes analíticos seguiu aqueles definidos na legislação, para minimizar possíveis erros metodológicos garantindo dessa forma a confiabilidade dos resultados obtidos. 
Para o monitoramento da concentração de fungos, foram utilizados como marcador epidemiológico fungos viáveis, sendo o método de amostragem feito através do uso de amostrador de ar por impactação com acelerador linear. O amostrador é do tipo impactador de 1,2 ou 6 estágios. O meio de cultivo utilizado foi agar extrato de malte e a taxa de vazão de 25 a 35 litros / minuto. O tempo de amostragem foi de 10 minutos, sendo a embalagem do material coletado e o transporte protegido com nível de biosegurança, recomendado para este tipo de teste. A precisão do resultado é de $99,92 \%$.

O procedimento laboratorial considerou o tempo mínimo de incubação de 7 dias a $25^{\circ} \mathrm{C}$, permitindo o total crescimento dos fungos.

Para o monitoramento da concentração de material particulado, foi utilizado como marcador epidemiológico a poeira total $\left(\mathrm{mg} / \mathrm{m}^{3}\right)$, e o método de amostragem foi feito através da coleta de aerodispersóides por filtração. $O$ amostrador é uma unidade de captação constituída por filtros de PVC, diâmetro de 37 milímetros e porosidade de 5 milímetros de diâmetro de poro específico para poeira total a ser coletada. Deve ter ainda suporte de filtro em disco de celulose, porta-filtro em plástico transparente com o mesmo diâmetro da unidade de captação. Foi utilizada uma bomba de amostragem, que mantém durante o período da coleta vazão inicial calibrada. O volume mínimo a ser coletado é de 50 litros, com uma taxa de vazão de 1,0 a 3,0 litros / minuto. O tempo de amostragem estipulado é de 50 litros por 17 minutos ou 400 litros para 133 minutos. A precisão do resultado é de $95 \%$.

Para o monitoramento da concentração de dióxido de carbono (marcador epidemiológico), foi utilizado equipamento de leitura direta através do uso 
de sensor infravermelho não dispersivo ou célula eletroquímica. A faixa do equipamento varia de 0 a 5000 ppm, sendo a precisão do resultado de mais ou menos $50 \mathrm{ppm}$ mais $2 \%$ do valor medido.

Para o monitoramento dos demais parâmetros de temperatura, umidade e velocidade do ar, os equipamentos utilizados também foram de leitura direta (termo higrômetro e termo anemômetro). $\mathrm{O}$ amostrador termo higrômetro possui um sensor de temperatura do tipo termo-resistência, enquanto que o sensor de umidade é do tipo capacitivo ou por condutividade elétrica. A precisão dos valores para a temperatura é de mais ou menos $0,8^{\circ} \mathrm{C}$ (com faixa de medição entre 0 a $70^{\circ} \mathrm{C}$ ) e para umidade de 95\% (com faixa de 5 a 95\%). Para a velocidade, o princípio de operação é o sensor de velocidade do ar do tipo fio aquecido ou fio térmico. A precisão é de mais ou menos $0,03 \mathrm{~m} / \mathrm{s}$ e $4 \%$ do valor medido, sendo a faixa de medição de 0 a $10 \mathrm{~m} / \mathrm{s}$. 


\section{RESULTADOS}

O primeiro resultado avaliado na bibliografia refere-se ao estudo realizado em ambiente de escritório comum com mais de cinco anos de funcionamento, com equipamento de condicionamento de ar ambiental não tratado. Foi ainda significativo para a escolha do local a facilidade de acesso ao sistema de retorno de ar do equipamento, onde seria aplicado o processo de higienização ambiental.

Os marcadores epidemiológicos escolhidos foram contagem total de bactérias, contagem total de fungos e avaliação bioparticulada.

Realizaram-se as seguintes análises:

- uma amostragem de ar no sistema de retorno de ar do equipamento,

- duas no ambiente de trabalho: sendo uma próxima e outra distante da saída do sistema de ar condicionado e

- uma no ambiente exterior para referencial comparativo.

A primeira amostragem ( dia 14 de março) foi realizada 24 horas antes do processo de higienização, como controle da situação do sistema. Após o período acima, foi efetuado o processo de higienização, seguindo os procedimentos utilizados pela prestadora de serviço. Passadas 24 horas do processo de higienização, foi coletada uma nova análise (18 de março), como controle do processo, e, 
posteriormente amostras seqüenciais foram executadas mensalmente, durante um periodo de seis meses. Os resultados estão apresentados nas tabelas abaixo.

Tabela 01: Valores referentes à distribuição do comportamento microbiológico (fungos e bactérias) e material bioparticulado, observados no retorno do ar do equipamento.

\begin{tabular}{|l|r|r|r|r|r|r|r|}
\hline Data & $14 / \mathrm{mar}$ & $18 / \mathrm{mar}$ & $18 /$ abr & $18 / \mathrm{mai}$ & $18 /$ jun & $18 /$ jul & $18 /$ ago \\
\hline Fungos (ufc/m ${ }^{3}$ ) & 161,8 & 56,9 & 85,6 & 45,2 & 147,4 & 312,9 & 326 \\
\hline Bactérias (ufc/m ${ }^{3}$ ) & 72,8 & 25,6 & 34,2 & 18 & 58,9 & 125,1 & 130,4 \\
\hline Material Bioparticulado & 114,8 & 42,8 & 59,2 & 35,7 & 123,8 & 157,1 & 204,7 \\
$\left(\right.$ ufc $\left./ \mathrm{m}^{3}\right)$ & & & & & & & \\
\hline Fungos ufc $/ \mathrm{m}^{3}$ (outdoor) & 17,1 & 17,1 & 17,1 & 17,1 & 17,1 & 17,1 & 17,1 \\
\hline Bactérias ufc $/ \mathrm{m}^{3}$ (outdoor) & 42,9 & 42,9 & 42,9 & 42,9 & 42,9 & 42,9 & 42,9 \\
\hline
\end{tabular}

Fonte: Revista Brasindoor 1.996 Volume I $\mathrm{n}^{\circ} 2$

Tabela 02: Valores referentes à distribuição do comportamento microbiológico (fungos e bactérias) e material bioparticulado, observados próximos ao sistema do ar condicionado.

\begin{tabular}{|c|c|c|c|c|c|c|c|}
\hline Data & $14 / \mathrm{mar}$ & $18 / \mathrm{mar}$ & 18/abr & $18 / \mathrm{mai}$ & $18 /$ jun & 18/jul & 18/ago \\
\hline Fungos $\left(\mathrm{ufc} / \mathrm{m}^{3}\right)$ & 173,5 & 64,1 & 164,2 & 47,6 & 95,1 & 171,3 & 209,3 \\
\hline Bactérias (ufc $/ \mathrm{m}^{3}$ ) & 78,1 & 28,8 & 65,6 & 19 & 38 & 68,5 & 83,7 \\
\hline $\begin{array}{l}\text { Material Bioparticulado } \\
\left(\mathrm{ufc} / \mathrm{m}^{3}\right)\end{array}$ & 92,8 & 42,8 & 33,3 & 21,4 & 83,3 & 66,6 & 111,9 \\
\hline Fungos $\mathrm{ufc} / \mathrm{m}^{3}$ (outdoor) & 17,1 & 17,1 & 17,1 & 17,1 & 17,1 & 17,1 & 17,1 \\
\hline Bactérias ufc $/ \mathrm{m}^{3}$ (outdoor) & 42,9 & 42,9 & 42,9 & 42,9 & 42,9 & 42,9 & 42,9 \\
\hline
\end{tabular}

Fonte: Revista Brasindoor 1.996 Volume I n 2 
Tabela 03: Valores referentes à distribuição do comportamento microbiológico (fungos e bactérias) e material bioparticulado, observados distantes do sistema de ar condicionado.

\begin{tabular}{|c|c|c|c|c|c|c|c|}
\hline Data & $14 / \mathrm{mar}$ & $18 / \mathrm{mar}$ & 18/abr & 18/mai & 18/jun & 18/jul & 18/ago \\
\hline Fungos $\left(\mathrm{ufc} / \mathrm{m}^{3}\right)$ & 107 & 37,9 & 499,4 & 54,8 & 235,5 & 237,8 & 361,9 \\
\hline Bactérias (ufc/m $\left./ \mathrm{m}^{3}\right)$ & 48,1 & 17 & 199,7 & 21,9 & 94,2 & 95,1 & 144,7 \\
\hline $\begin{array}{l}\text { Material Bioparticulado } \\
\left(\mathrm{ufc} / \mathrm{m}^{3}\right)\end{array}$ & 30,9 & 14,2 & 154,7 & 45,2 & 219 & 197,6 & 171,4 \\
\hline Fungos ufc/m $/ \mathrm{m}^{3}$ (outdoor) & 17,1 & 17,1 & 17,1 & 17,1 & 17,1 & 17,1 & 17,1 \\
\hline Bactérias ufc $/ \mathrm{m}^{3}$ (outdoor) & 42,9 & 42,9 & 42,9 & 42,9 & 42,9 & 42,9 & 42,9 \\
\hline
\end{tabular}

Fonte: Revista Brasindoor 1.996 Volume $\mathrm{I} \mathrm{n}^{\circ} 2$

O segundo estudo apresentado refere-se a valores amostrados entre os anos de 1993 e 1995 em uma indústria química. Durante este período foram realizadas análises de diagnóstico, processos de intervenção e análises de controle. O foco deste trabalho foi a bandeja de condensado de cinco áreas distintas da fábrica, sendo as análises coletadas na água e no biofilme acumulado, antes e depois do processo de higienização das bandejas. A escolha das áreas deveu-se ao número de colaboradores expostos, exercendo funções administrativas distintas.

As tabelas apresentam os valores obtidos na coleta do material, conforme os pontos de amostragem e os procedimentos acima apresentados. 
Tabela 04: Resultados de monitoramento da concentração de bactérias e fungos na água da bandeja do condensado, antes e depois do processo de higienização.

\begin{tabular}{|l|r|r|r|r|}
\hline Local & $\begin{array}{l}\text { Concentração } \\
\text { bacteriana } \\
(\mathrm{ufc} / \mathrm{ml})\end{array}$ & $\begin{array}{l}\text { Concentração } \\
\text { bacteriana } \\
(\mathrm{ufc} / \mathrm{ml})\end{array}$ & $\begin{array}{l}\text { Concentração } \\
\text { fúngica } \\
(\mathrm{ufc} / \mathrm{ml})\end{array}$ & $\begin{array}{l}\text { Concentração } \\
\text { fúngica } \\
(\mathrm{ufc} / \mathrm{ml})\end{array}$ \\
\hline Área comercial 01 & 720.000 & 540.000 & 11.000 & 69.000 \\
\hline Área comercial 02 & 840.000 & 32.000 & 13.000 & 43.000 \\
\hline Biblioteca & 780.000 & 250.000 & 12.000 & 12.000 \\
\hline Laboratório & 860.000 & 38.000 & 9.100 & 50.000 \\
\hline Recepção & 92.000 .000 & 400.000 & 17.000 & 52.000 \\
\hline Restaurante & 880.000 & 1.400 & 20.000 & 3.200 \\
\hline
\end{tabular}

Fonte: Revista Brasindoor 1.997 Volume II n ${ }^{\circ} 6$

Tabela 05: Resultados de monitoramento da concentração de bactérias e fungos no biofilme da bandeja do condensado, antes e depois do processo de higienização.

\begin{tabular}{|l|r|r|r|r|}
\hline Local & $\begin{array}{l}\text { Concentração } \\
\text { bacteriana } \\
(\mathrm{ufc} / \mathrm{ml})\end{array}$ & $\begin{array}{l}\text { Concentração } \\
\text { bacteriana } \\
(\mathrm{ufc} / \mathrm{ml})\end{array}$ & $\begin{array}{l}\text { Concentração } \\
\text { fúngica } \\
(\mathrm{ufc} / \mathrm{ml})\end{array}$ & $\begin{array}{l}\text { Concentração } \\
\text { fúngica } \\
(\mathrm{ufc} / \mathrm{ml})\end{array}$ \\
\hline Área comercial 01 & 86.000 .000 & 1.500 .000 & 4.500 .000 & 6.400 .000 \\
\hline Área comercial 02 & 78.000 .000 & 8.100 .000 & 6.100 .000 & 550.000 \\
\hline Biblioteca & 82.000 .000 & 1.600 .000 & 9.200 .000 & 500.000 \\
\hline Laboratório & 92.000 .000 & 5.000 .000 & 4.000 .000 & 580.000 \\
\hline Recepção & 98.000 .000 & 6.000 .000 & 490.000 & 84.000 \\
\hline Restaurante & 74.000 .000 & 50.000 & 3.900 .000 & 4.500 \\
\hline
\end{tabular}

Fonte: Revista Brasindoor 1.997 Volume II n ${ }^{\circ} 6$ 
O terceiro estudo refere-se à pesquisa realizada em uma área pública com grande circulação de pessoas (cerca de 80.000 por dia). O parâmetro analítico utilizado foi a concentração de microorganismos (fungos) no ar ambiental, a partir de amostragens periódicas coletadas semestralmente. Os resultados observados referemse à média das concentrações referentes aos cinqüenta pontos amostrados. A primeira amostragem marca uma situação de diagnóstico, sendo as demais avaliadas em função das atividades de manutenção e procedimentos de higienização do sistema.

Tabela 06: Média dos cinqüenta pontos obtidos nos resultados de monitoramento do sistema de ar condicionado.

\begin{tabular}{|c|c|}
\hline Data da análise & Concentração de fungos $\left(\mathrm{ufc} / \mathrm{m}^{3}\right)$ \\
\hline Março - 95 & 61,9 \\
\hline Setembro - 95 & 4,8 \\
\hline Março - 96 & 224,9 \\
\hline Setembro - 96 & 221,0 \\
\hline Março - 97 & 78,5 \\
\hline
\end{tabular}

Fonte: Revista Brasindoor 1.997 Volume II n ${ }^{\circ} 6$

O quarto estudo baseia-se nas avaliações efetuadas em um shopping center da cidade de São Paulo onde transitam em média 100.000 pessoas por fim de semana. Os valores obtidos referem-se à média dos 29 pontos de coleta de amostras. O parâmetro utilizado foi a contagem de fungos em suspensão (concentração). A campanha de coleta de amostras de 1.999 serviu como referência comparativa para a segunda análise realizada um ano após a implantação de medidas preventivas relacionadas com as ações de manutenção e higienização do sistema de ar condicionado. 
Tabela 07: Média dos resultados de monitoramento obtidos no sistema de ar condicionado.

\begin{tabular}{|c|c|c|}
\hline Data das amostras & $\begin{array}{c}\text { Intervalo dos resultados } \\
\left(\mathrm{ufc} / \mathrm{m}^{3}\right)\end{array}$ & $\begin{array}{c}\text { Concentração média de } \\
\text { fungos }\left(\mathrm{ufc} / \mathrm{m}^{3}\right)\end{array}$ \\
\hline 1.999 & 14,3 até 135,7 & 57,1 \\
\hline 2.000 & 7,1 até 78,6 & 27,8 \\
\hline
\end{tabular}

Fonte: Revista Brasindoor 2.000 Volume IV n⿳3

$\mathrm{O}$ último estudo e caso piloto refere-se àquele efetuado em uma indústria farmacêutica, durante o período de um ano, tendo sido coletadas três amostras: a primeira em setembro de 2.003 , a segunda seis meses depois, em março de 2.004 e a última em setembro do mesmo ano. Houve como objetivo principal confrontar os valores obtidos com aqueles definidos na legislação vigente, bem como avaliar as práticas de manutenção realizadas, frente aos resultados obtidos. As tabelas a seguir apresentam os valores obtidos por parâmetro legal.

$\mathrm{O}$ número de pontos foi definido a partir da premissa legal, que estabelece a quantidade recomendada em função da área climatizada, sendo que para o caso em questão temos entre $10.000 \mathrm{~m}^{2}$ e $15.000 \mathrm{~m}^{2}$ de área construída e devem ser coletadas amostras em 15 pontos distintos. 
Tabela 08: Resultados de monitoramento obtidos para as análises de umidade e temperatura.

\begin{tabular}{|c|c|c|c|c|c|c|}
\hline \multirow[b]{2}{*}{ Pontos de Coleta } & \multicolumn{3}{|c|}{ Umidade (\%) } & \multicolumn{3}{|c|}{ Temperatura $\left({ }^{\circ} \mathrm{C}\right)$} \\
\hline & set/03 & $\mathrm{mar} / 04$ & set/04 & set/03 & $\mathrm{mar} / 04$ & set/04 \\
\hline Área de Informática & 51,5 & 47,4 & 61,2 & 24,8 & 26,8 & 20,4 \\
\hline Área Administrativa 01 & 54,3 & 68,9 & 61,7 & 23,1 & 25,2 & 20,6 \\
\hline Ambulatório Médico & 56,5 & 51,2 & 59,7 & 23,2 & 25,5 & 21,4 \\
\hline Área Administrativa 02 & 56,3 & 66,9 & 52,9 & 23,6 & 25,1 & 22,9 \\
\hline Sala de Microbiologia & 54,4 & 57,4 & 54,3 & 24,6 & 25,7 & 23,4 \\
\hline Restaurante & 52,2 & 54,5 & 58,8 & 23,1 & 24,4 & 24,0 \\
\hline Área Administrativa 03 & 57,9 & 52,8 & 64,1 & 23,1 & 25 & 19,5 \\
\hline Área de Injetáveis & 51,0 & 64,9 & 65,1 & 23,3 & 24,2 & 23,8 \\
\hline Área de Produção 01 & 52,6 & 54,2 & 61,1 & 23,8 & 24,1 & 20,2 \\
\hline Área de Efervescentes & 58,0 & 27,9 & 61,3 & 24,6 & 23,3 & 20,1 \\
\hline Área de Compressão & 51,8 & 57,3 & 60,1 & 23,3 & 23,5 & 20,3 \\
\hline Área de Drageamento & 51,7 & 59,6 & 50,1 & 23,1 & 23,2 & 23,1 \\
\hline Área de Embalagem 01 & 55,2 & 30,6 & 60,1 & 23,7 & 29,7 & 20,1 \\
\hline Área de Tecnologia & 58,3 & 63,2 & 58,1 & 24,8 & 23,6 & 23,4 \\
\hline Área de Embalagem 02 & 56,3 & 58,0 & 58,1 & 23,7 & 23,4 & 22,1 \\
\hline
\end{tabular}

O valor recomendado para a umidade está definido entre 40 e $65 \%$, enquanto que para a temperatura a faixa é de 23 a $26^{\circ} \mathrm{C}$. 
Tabela 09: Resultados de monitoramento obtidos para velocidade do ar e concentração de $\mathrm{CO}_{2}$.

\begin{tabular}{|l|r|r|r|r|r|r|}
\hline & \multicolumn{2}{|c|}{ Velocidade do Ar } & \multicolumn{2}{c|}{ Concentração de $\mathrm{CO}_{2}$} \\
\hline Pontos de Coleta & set/03 & mar/04 & set/04 & set/03 & mar/04 & set/04 \\
\hline Área de Informática & 0,02 & 0,06 & $<0,25$ & 908 & 945 & 436 \\
\hline Área Administrativa 01 & 0,01 & 0,01 & $<0,25$ & 662 & 967 & 352 \\
\hline Ambulatório Médico & 0,06 & 0,03 & $<0,25$ & 488 & 912 & 420 \\
\hline Área Administrativa 02 & 0,01 & 0,05 & $<0,25$ & 528 & 834 & 344 \\
\hline Sala de Microbiologia & 0,02 & 0,08 & $<0,25$ & 561 & 863 & 333 \\
\hline Restaurante & 0,01 & 0,01 & $<0,25$ & 440 & 1.024 & 812 \\
\hline Área Administrativa 03 & 0,03 & 0,01 & $<0,25$ & 436 & 792 & 322 \\
\hline Área de Injetáveis & 0,01 & 0,03 & $<0,25$ & 510 & 1.104 & 517 \\
\hline Área de Produção 01 & 0,01 & 0,06 & $<0,25$ & 620 & 879 & 430 \\
\hline Área de Efervescentes & 0,02 & 0,02 & $<0,25$ & 508 & 844 & 418 \\
\hline Área de Compressão & 0,01 & 0,01 & $<0,25$ & 514 & 793 & 512 \\
\hline Área de Drageamento & 0,09 & 0,01 & $<0,25$ & 526 & 781 & 616 \\
\hline Área de Embalagem 01 & 0,01 & 0,01 & $<0,25$ & 492 & 847 & 581 \\
\hline Área de Tecnologia & 0,06 & 0,01 & $<0,25$ & 667 & 1.176 & 781 \\
\hline Área de Embalagem 02 & 0,07 & 0,01 & $<0,25$ & 543 & 800 & 720 \\
\hline
\end{tabular}

O valor recomendado para a velocidade do ar é que esteja abaixo de $0,25 \mathrm{~m} / \mathrm{s}$. Embora a legislação defina critérios para a umidade, temperatura e velocidade do ar, estes parâmetros podem ser considerados como condição de conforto. Apesar destes estarem relacionados com o conforto, apresentam significativa interferência no crescimento dos microorganismos nos sistemas 
condicionados, principalmente considerando a umidade, que favorece o crescimento e a velocidade do ar, que pode auxiliar na dispersão dos poluentes. Para o dióxido de carbono $\left(\mathrm{CO}_{2}\right)$, o valor máximo estabelecido pela legislação é de 1.000 ppm.

Tabela 10: Resultados de monitoramento dos valores para a concentração de fungos e de material particulado.

\begin{tabular}{|c|c|c|c|c|c|c|}
\hline & \multicolumn{3}{|c|}{$\begin{array}{l}\text { Concentração de } \\
\text { fungos }\left(\mathrm{ufc} / \mathrm{m}^{3}\right)\end{array}$} & \multicolumn{3}{|c|}{$\begin{array}{l}\text { Concentração material } \\
\text { particulado }\left(\mathrm{mg} / \mathrm{m}^{3}\right)\end{array}$} \\
\hline Pontos de Coleta & set/03 & $\mathrm{mar} / 04$ & set/04 & Set/03 & $\mathrm{mar} / 04$ & set $/ 04$ \\
\hline Área de Informática & 21,4 & 35,7 & 42,9 & 0,19 & 0,75 & 0,75 \\
\hline Área Administrativa 01 & 50,0 & 14,3 & 14,3 & 0,75 & 0,19 & 0,19 \\
\hline Ambulatório Médico & 50,0 & 57,1 & 78,6 & 1,13 & 0,19 & 0,57 \\
\hline Área Administrativa 02 & 28,6 & 42,9 & 35,7 & 0,19 & 0,38 & 0,19 \\
\hline Sala de Microbiologia & 14,3 & 35,7 & 50 & 0,19 & 0,57 & 0,38 \\
\hline Restaurante & 78,6 & 50 & 71,4 & 0,94 & 0,57 & 0,19 \\
\hline Área Administrativa 03 & 21,4 & 28,6 & 28,6 & 0,19 & 0,19 & 0,38 \\
\hline Área de Injetáveis & 7,1 & 42,9 & 21,4 & 0,38 & 0,94 & 0,38 \\
\hline Área de Produção 01 & 14,3 & 28,6 & 28,6 & 0,19 & 0,19 & 0,19 \\
\hline Área de Efervescentes & 28,6 & 21,4 & 7,1 & 0,38 & 0,57 & 0,38 \\
\hline Área de Compressão & 14,3 & 64,3 & 28,6 & 0,19 & 0,38 & 0,57 \\
\hline Área de Drageamento & 28,6 & 14,3 & 14,3 & 0,19 & 0,38 & 0,19 \\
\hline Área de Embalagem 01 & 7,1 & 7,1 & 7,1 & 0,19 & 0,19 & 0,57 \\
\hline Área de Tecnologia & 14,3 & 14,3 & 28,6 & 0,75 & 0,19 & 0,38 \\
\hline Área de Embalagem 02 & 21,4 & 42,9 & 14,3 & 0,19 & 0,19 & 0,38 \\
\hline
\end{tabular}

Os valores máximos estabelecidos para fungos e material particulado são $750 \mathrm{ufc} / \mathrm{m}^{3}$ e $80 \mathrm{mg} / \mathrm{m}^{3}$, respectivamente. 
Tabela 11: Resultados dos valores obtidos para a relação I/E.

\begin{tabular}{|l|r|r|r|}
\hline & \multicolumn{3}{|c|}{$\mathrm{I} / \mathrm{E}$} \\
\hline Pontos de Coleta & \multicolumn{1}{|c|}{ set/03 } & mar/04 & set/04 \\
\hline Área de Informática & \multicolumn{1}{|c|}{0,17} & 0,31 & 0,37 \\
\hline Área Administrativa 01 & \multicolumn{1}{|c|}{0,39} & 0,12 & 0,12 \\
\hline Ambulatório Médico & \multicolumn{1}{|c|}{0,39} & 0,5 & 0,69 \\
\hline Área Administrativa 02 & 0,22 & 0,37 & 0,31 \\
\hline Sala de Microbiologia & 0,11 & 0,31 & 0,44 \\
\hline Restaurante & \multicolumn{1}{|c|}{0,61} & 0,44 & 0,62 \\
\hline Área Administrativa 03 & 0,17 & 0,25 & 0,25 \\
\hline Área de Injetáveis & 0,06 & 0,37 & 0,19 \\
\hline Área de Produção 01 & 0,11 & 0,25 & 0,25 \\
\hline Área de Efervescentes & 0,22 & 0,19 & 0,06 \\
\hline Área de Compressão & 0,11 & 0,56 & 0,25 \\
\hline Área de Drageamento & 0,22 & 0,12 & 0,12 \\
\hline Área de Embalagem 01 & 0,06 & 0,06 & 0,06 \\
\hline Área de Tecnologia & 0,11 & 0,12 & 0,25 \\
\hline Área de Embalagem 02 & 0,17 & 0,37 & 0,12 \\
\hline
\end{tabular}

Para a relação $\mathrm{I} / \mathrm{E}$, que representa o quociente entre os valores obtidos para a concentração de fungos medida no ambiente interno (I) e no ambiente externo (E), o valor máximo permitido é de 1,5 . 


\section{DISCUSSÃo}

Os resultados acima apresentados estão analisados inicialmente de forma individualizada e, posteriormente, na conclusão do trabalho, os mesmos serão agrupados para evidenciar o alinhamento com os objetivos propostos.

A avaliação dos resultados obtidos, nas campanhas de coleta de amostras no escritório, mostram a significativa redução da concentração de fungos, bactérias e material particulado nos pontos amostrados: retorno do ar condicionado, pontos próximos e distantes da saída. Observa-se ainda que os níveis de microorganismos antes do processo de higienização se encontravam bem acima dos níveis dos microorganismos encontrados no ambiente exterior $\left(17,1 \mathrm{ufc} / \mathrm{m}^{3}\right.$ para os fungos e $42,9 \mathrm{ufc} / \mathrm{m}^{3}$ para as bactérias), sendo que, após o processo de limpeza realizado logo depois da primeira coleta (14 de março), os valores se aproximaram. Com o decorrer do tempo, percebe-se também aumento gradativo das concentrações de microorganismos sem que tenha sido realizado outro processo de intervenção (atividades de manutenção do sistema ou ainda higienização dos equipamentos).

Com relação à matéria bioparticulada, a concentração diminuiu acentuadamente, retornando às condições anteriores no período de sessenta dias. A avaliação da matéria bioparticulada é decisiva no critério de padronização dos procedimentos de higienização ambiental, pois, o risco relativo de agravos à saúde do trabalhador, por processos alergênicos, é diretamente proporcional à quantidade de matéria orgânica encontrada nos ambientes.

De maneira elucidativa, os gráficos abaixo comprovam as tendências de crescimento dos valores após a execução das atividades de manutenção. 


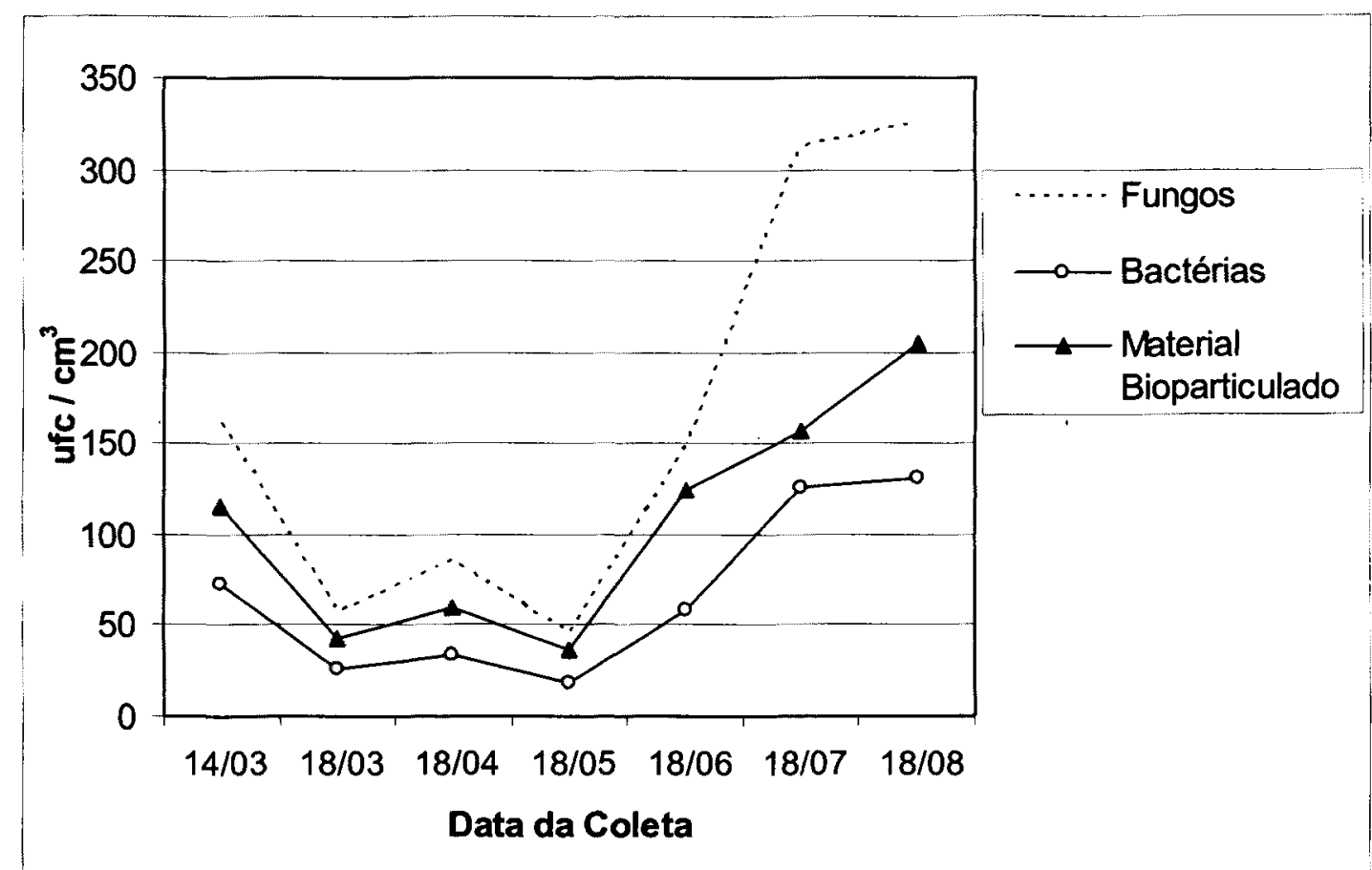

Gráfico 01: Concentração de poluentes amostrados no retorno do ar condicionado.

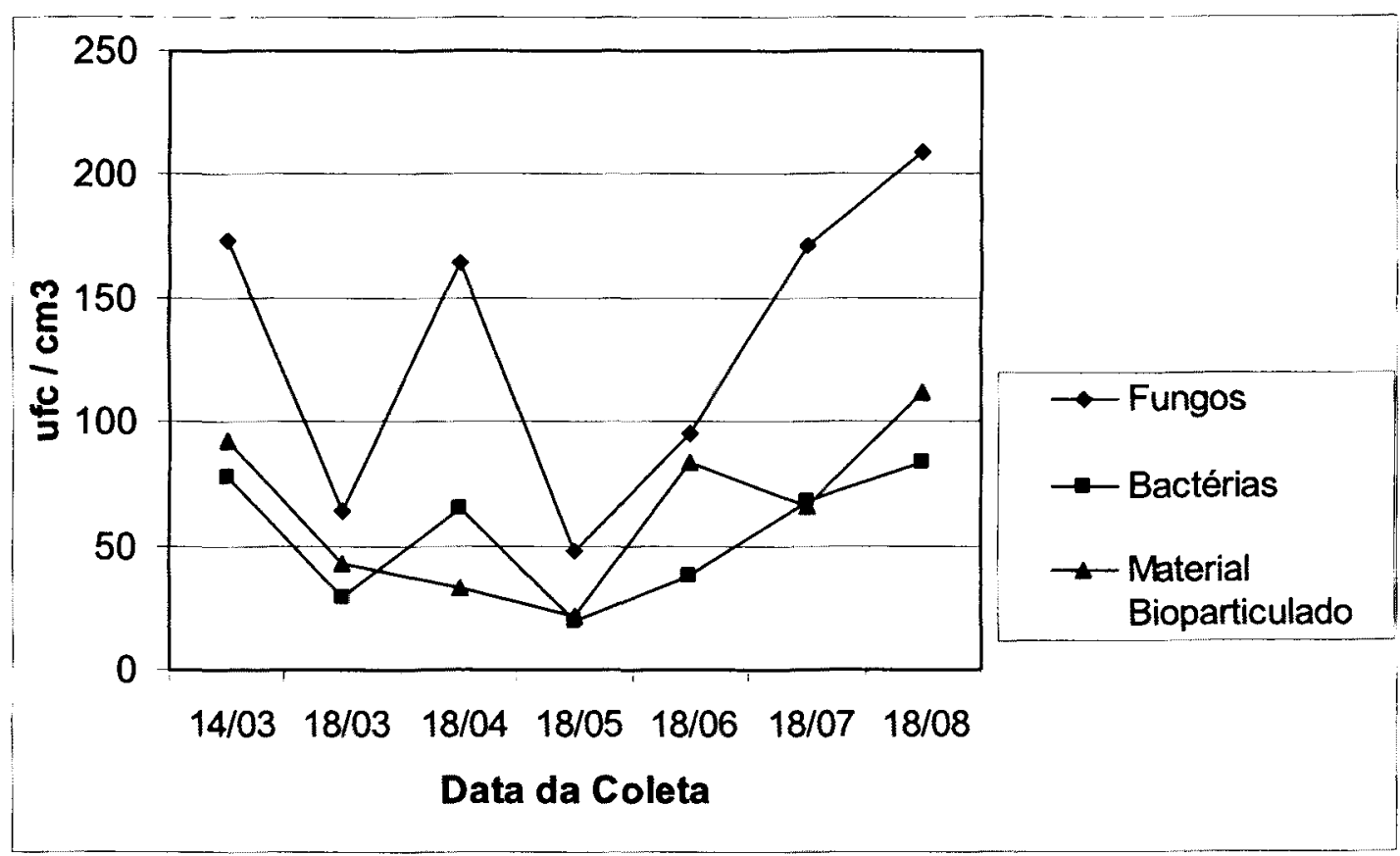

Gráfico 02: Concentração de poluentes amostrados próximos ao sistema de ar condicionado 


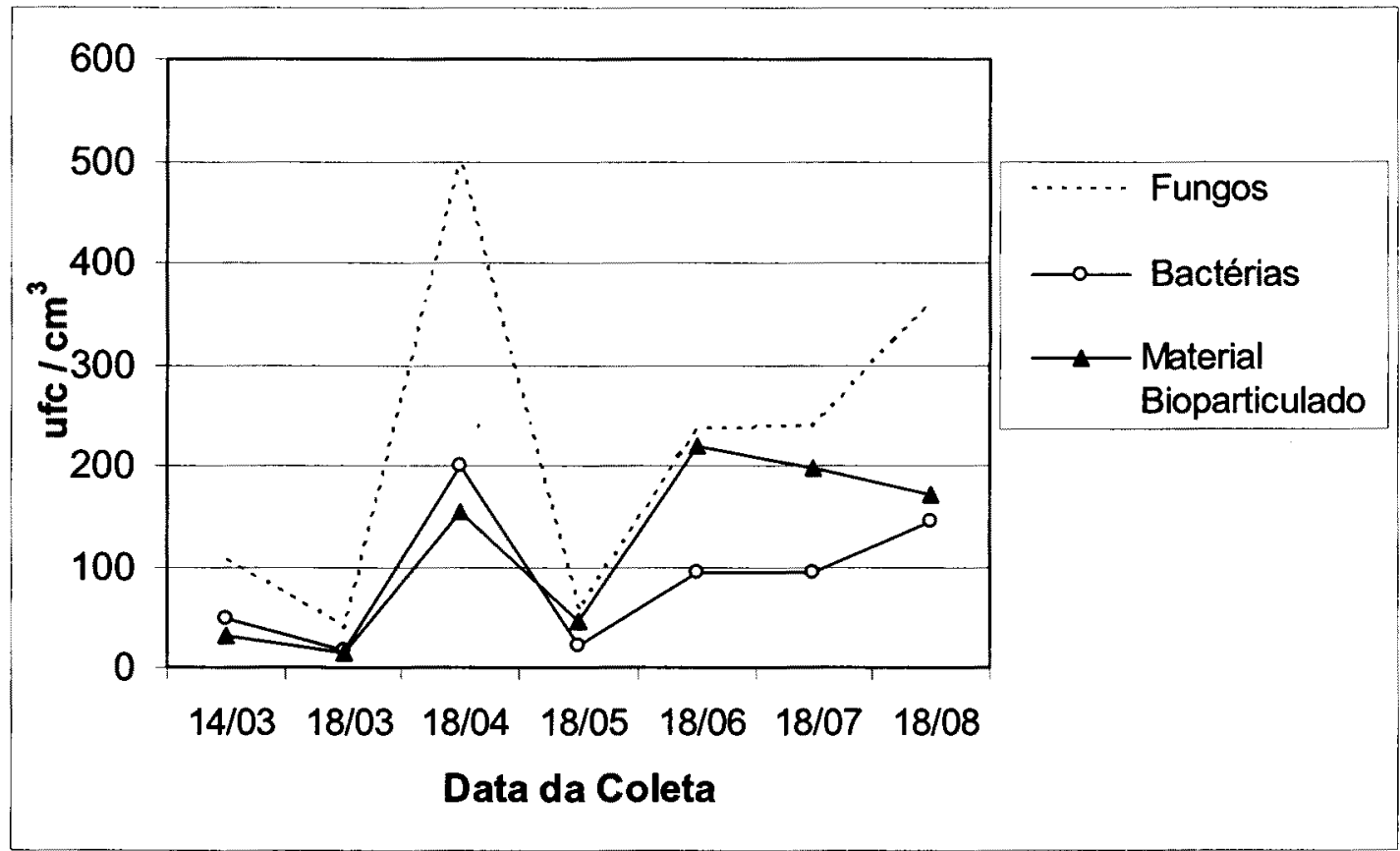

Gráfico 03: Concentração de poluentes coletados em um ponto distante do sistema de ar condicionado.

Os resultados obtidos, no segundo caso apresentado da indústria, encontram-se nos gráficos a seguir para melhor ilustrar as discussões.

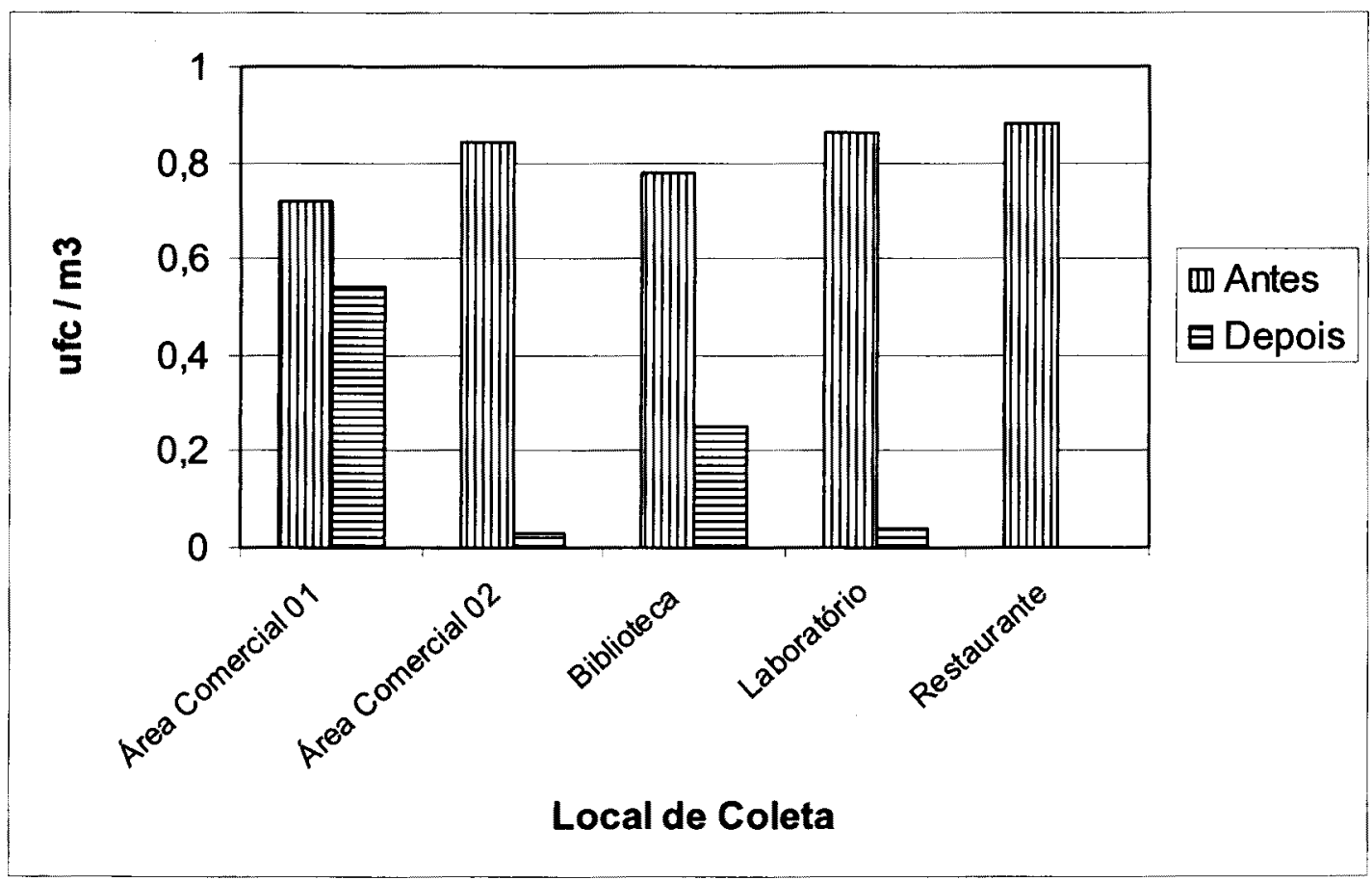

Gráfico 04: Concentração de bactérias presentes na água da bandeja de condensado, antes e depois do processo de intervenção. 
Em virtude da escala os valores obtidos na recepção não foram apresentados, pois, antes da intervenção, foram encontradas $92 \mathrm{ufc} / \mathrm{m}^{3}$ e depois 0,4 $\mathrm{ufc} / \mathrm{m}^{3}$.

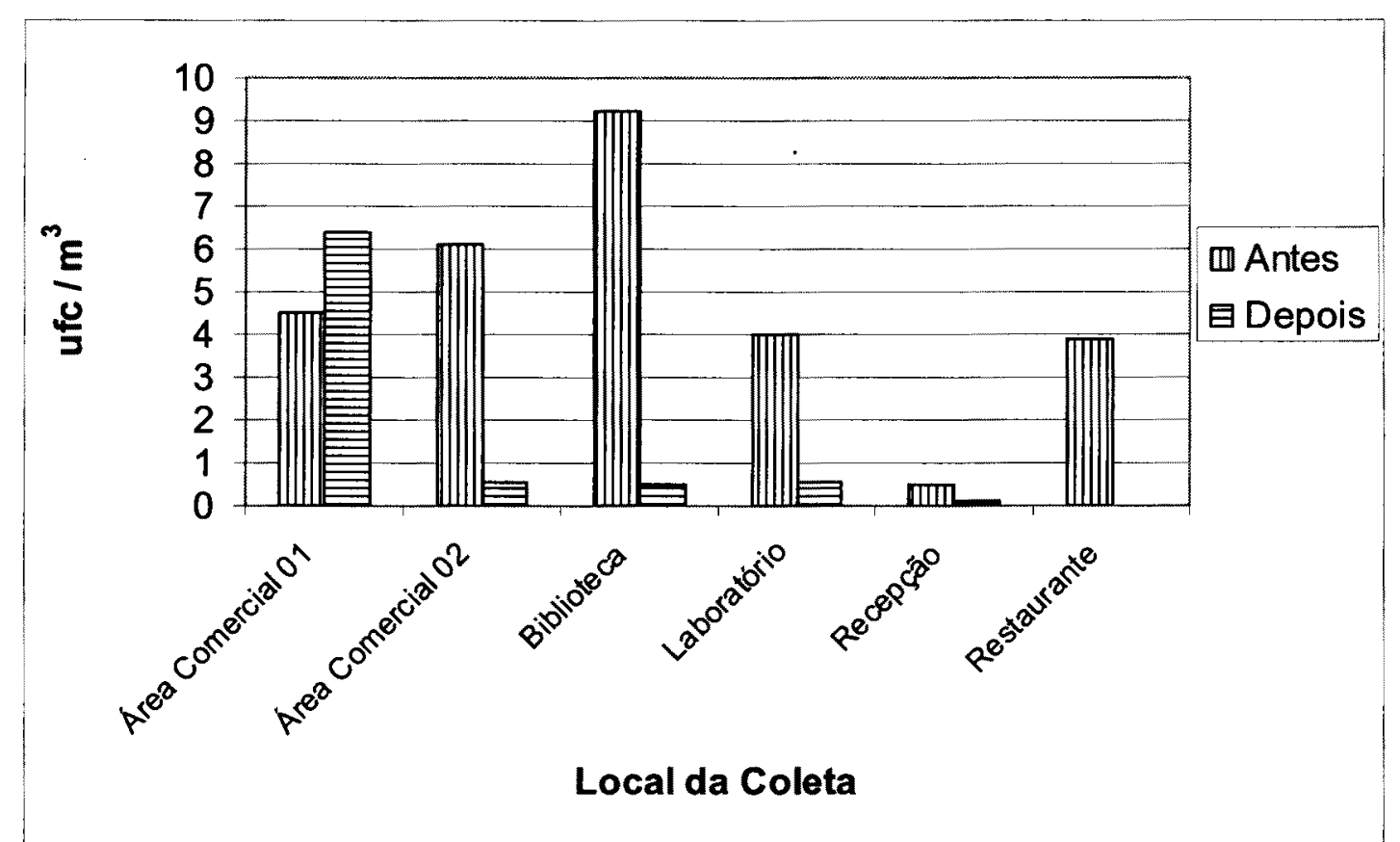

Gráfico 05: Concentração de bactérias presentes no biofilme da bandeja de condensado, antes e depois do processo de intervenção.

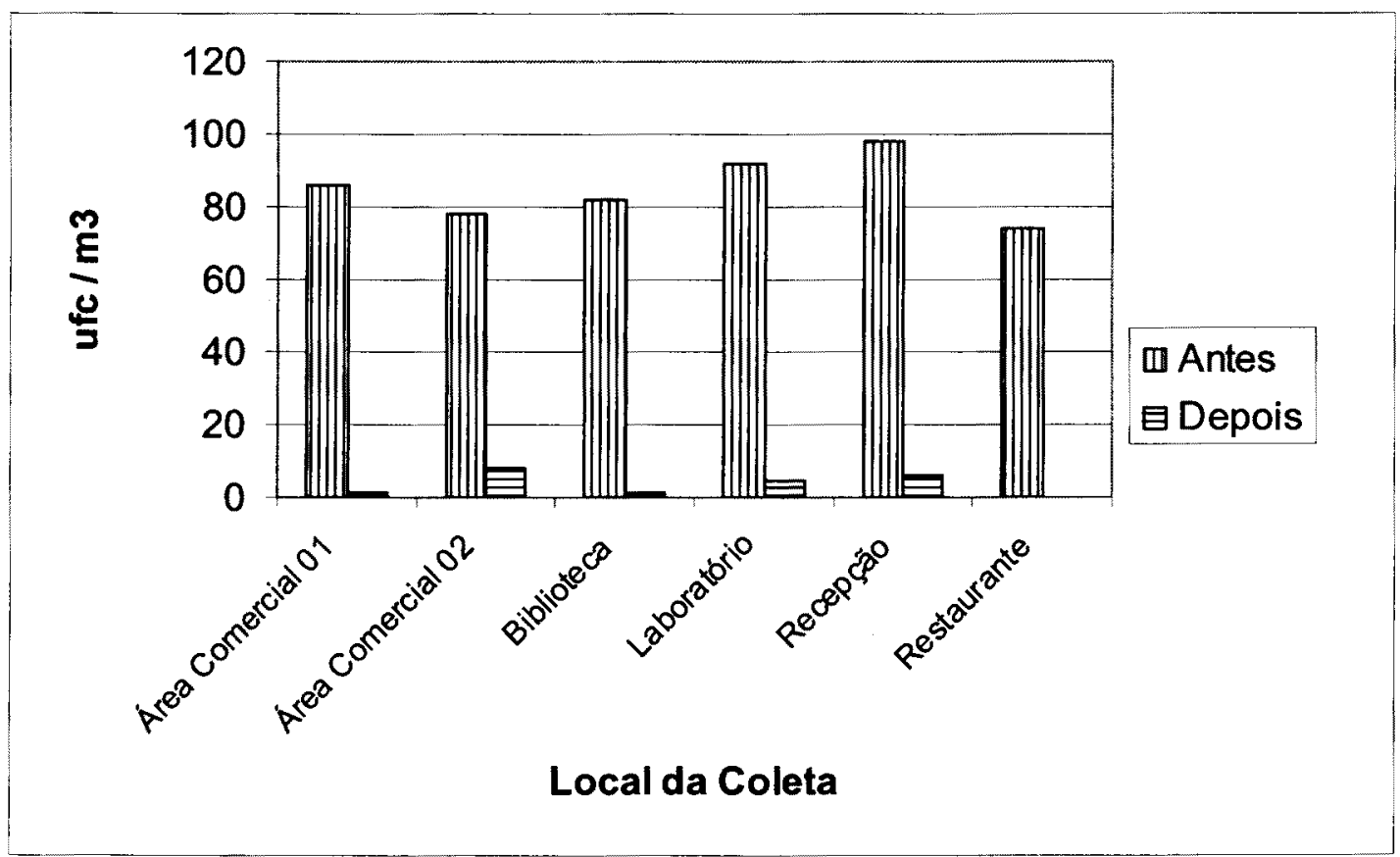

Gráfico 06: Concentração de fungos presentes no biofilme da bandeja de condensado, antes e depois do processo de intervenção. 
A fonte poluente primária demonstra, como resultado da primeira análise, um ecossistema complexo e abundante, representando significativo risco relativo ao processo de poluição biológica de interiores.

Após o processo de higienização, observa-se diminuição drástica do número de microorganismos no ar insuflado, mesmo considerando que, para a área comercial 01 , a concentração de fungos tenha apresentado aumento do valor inicial, representando uma ação de higienização feita de maneira inadequada.

O tratamento e controle das bandejas de condensado é um procedimento indispensável, uma vez que a microbiota, observada na análise da água e do biofilme, as caracterizam como principal fonte de poluente do sistema de ar condicionado central. Evidencia-se também a necessidade de padronização do processo de tratamento da água da bandeja de condensado porque os valores obtidos para a concentração de fungos, após a manutenção, não demonstraram o decaimento esperado.

Os dados obtidos, na pesquisa realizada, no sistema de ar condicionado de uma área pública com grande concentração, referente ao terceiro caso estudado, estão apresentados no gráfico número 7. 


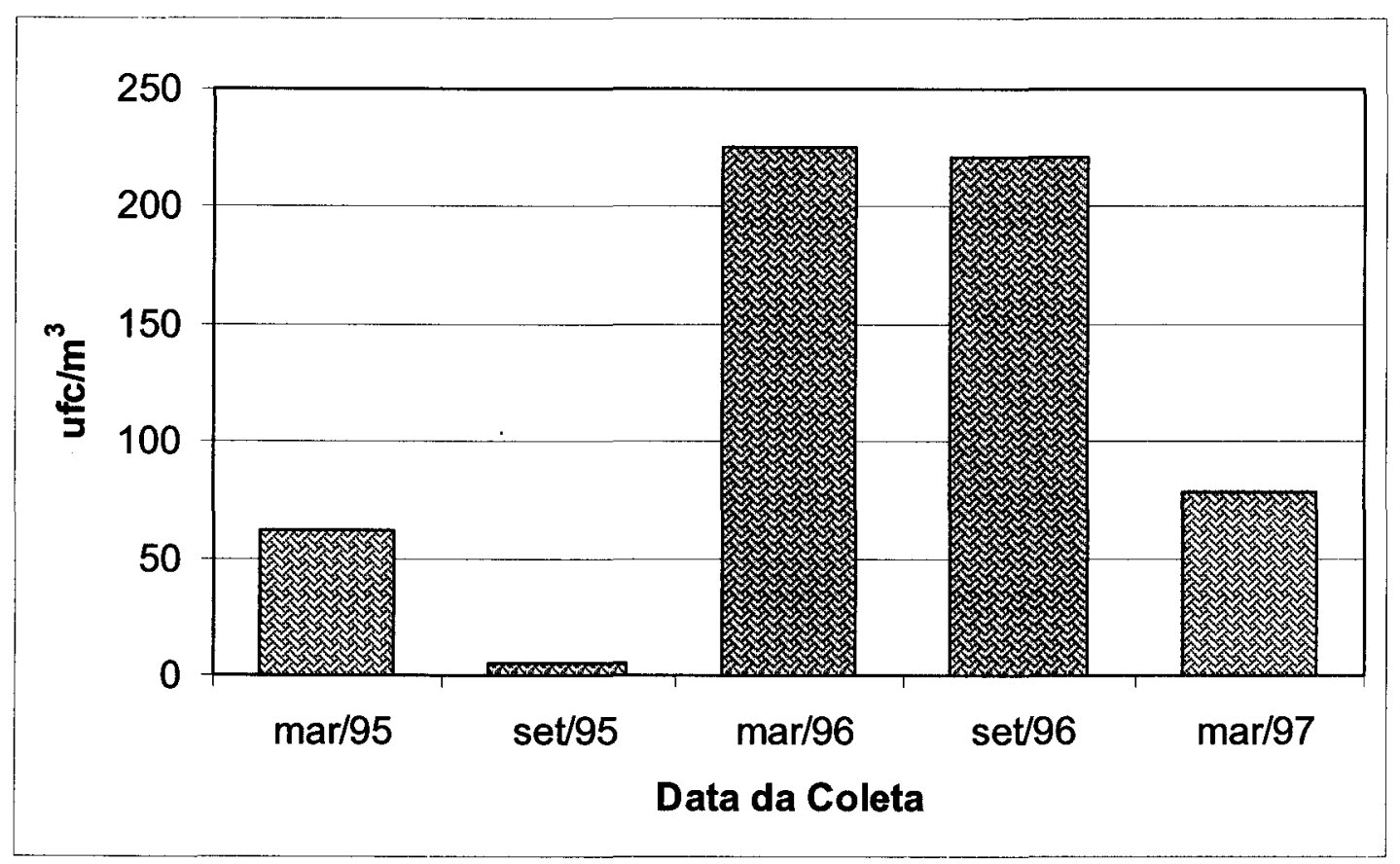

Gráfico 07: Concentração de fungos presentes no sistema de ar condicionado.

A primeira amostragem foi realizada em março de 95 , servindo como diagnóstico inicial da área em questão. Este diagnóstico permitiu a inserção de uma medida corretiva direcionada através da introdução do sistema de tratabilidade das máquinas com foco na eliminação da fonte primária de contaminação de origem biológica. A segunda amostragem, realizada seis meses depois (setembro de 1995), evidencia os resultados das medidas de intervenção adotadas como parte do programa de manutenção da qualidade do ar de interiores que foi implementado. Os resultados dos semestres subseqüentes comprovaram uma ineficiência dos processos de higienização com significativo aumento da concentração de fungos. A amostra realizada em março de 97 foi efetuada após novo processo de higienização monitorado e acompanhado por especialistas.

Destaca-se aqui que a falta de padronização dos processos de manutenção do sistema interfere diretamente nos resultados de monitoramento dos parâmetros de avaliação da contaminação microbiológica nos sistemas de ar 
condicionado, uma vez que a empresa, que efetuou as atividades de manutenção e higienização antes das análises realizadas em março e setembro de 96 , foi diferente daquela que realizou anteriormente aos meses de setembro de 95 e março de 97 , comprovado de maneira quantitativa pelos valores apresentados no gráfico comparativamente com o mês anterior.

Os resultados do quarto trabalho estudado referente ao monitoramento do sistema de ar condicionado de um shopping center de grande circulação estão apresentados no próximo gráfico:

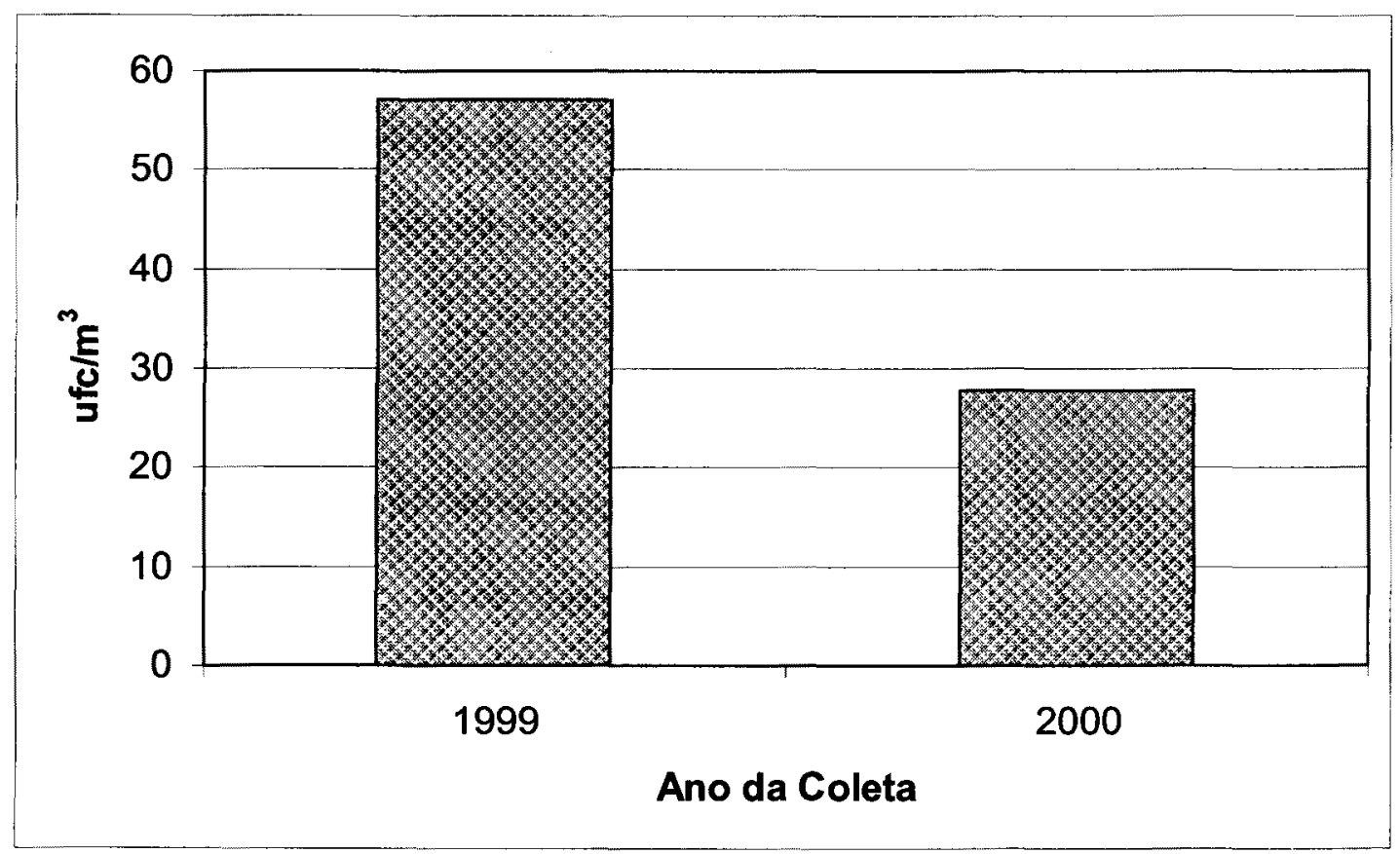

Gráfico 08: Valor médio da concentração de fungos entre os cinqüenta pontos amostrados.

Este trabalho apresentou um caso de implantação de um programa de controle das fontes poluentes, visando à garantia da qualidade do ar interior, no shopping center em estudo. As análises serviram como parâmetro para avaliar a qualidade dos serviços de manutenção executados, permitindo corrigir e redirecionar determinadas ações, isto é, a primeira coleta serve como referencial, uma vez que no 
período subseqüente de um ano, uma série de ações foi implementada. Destacam-se entre elas:

- instalação de filtros nos condicionadores, no retorno do ar e na tomada de ar externo;

- melhoria no acabamento da casa de máquina, facilitando a visualização da sujidade e as atividades de manutenção,

- controle do material particulado no interior do sistema, interferindo diretamente na concentração de microorganismos em função da dimensão dos mesmos e

- seleção de um produto químico não agressivo que funcionou como inibidor de biofilme nas bandejas de condensação.

Observa-se pelo gráfico que os valores obtidos, após a implantação das ações, demonstram significativa redução na concentração de fungos (acima de 50\%). No ano de 1.999 os valores encontrados ficaram entre 14,3 e $135,7 \mathrm{ufc} / \mathrm{m}^{3}$, enquanto que no ano seguinte os valores variaram entre 7,1 e $78,6 \mathrm{ufc} / \mathrm{m}^{3}$.

O quinto e último caso decorrente deste estudo reflete a eficiência das atividades de manutenção, implementadas na empresa piloto. Foram efetuadas três coletas de amostras durante um ano, e os resultados obtidos comparados com os parâmetros definidos pela legislação, diferentemente dos casos anteriores que apresentam apenas as concentrações de microorganismos. Desta forma este considera além da concentração de fungos, a concentração de material particulado e o índice comparativo com a concentração do ar exterior. Outros parâmetros, como a umidade, a temperatura, a velocidade do ar e a concentração de $\mathrm{CO}_{2}$, também 
possuem faixa recomendada ou limite e, além de servirem como indicadores para os contaminantes biológicos, são considerados como critérios de conforto, pois, podem interferir no bem-estar da pessoa exposta.

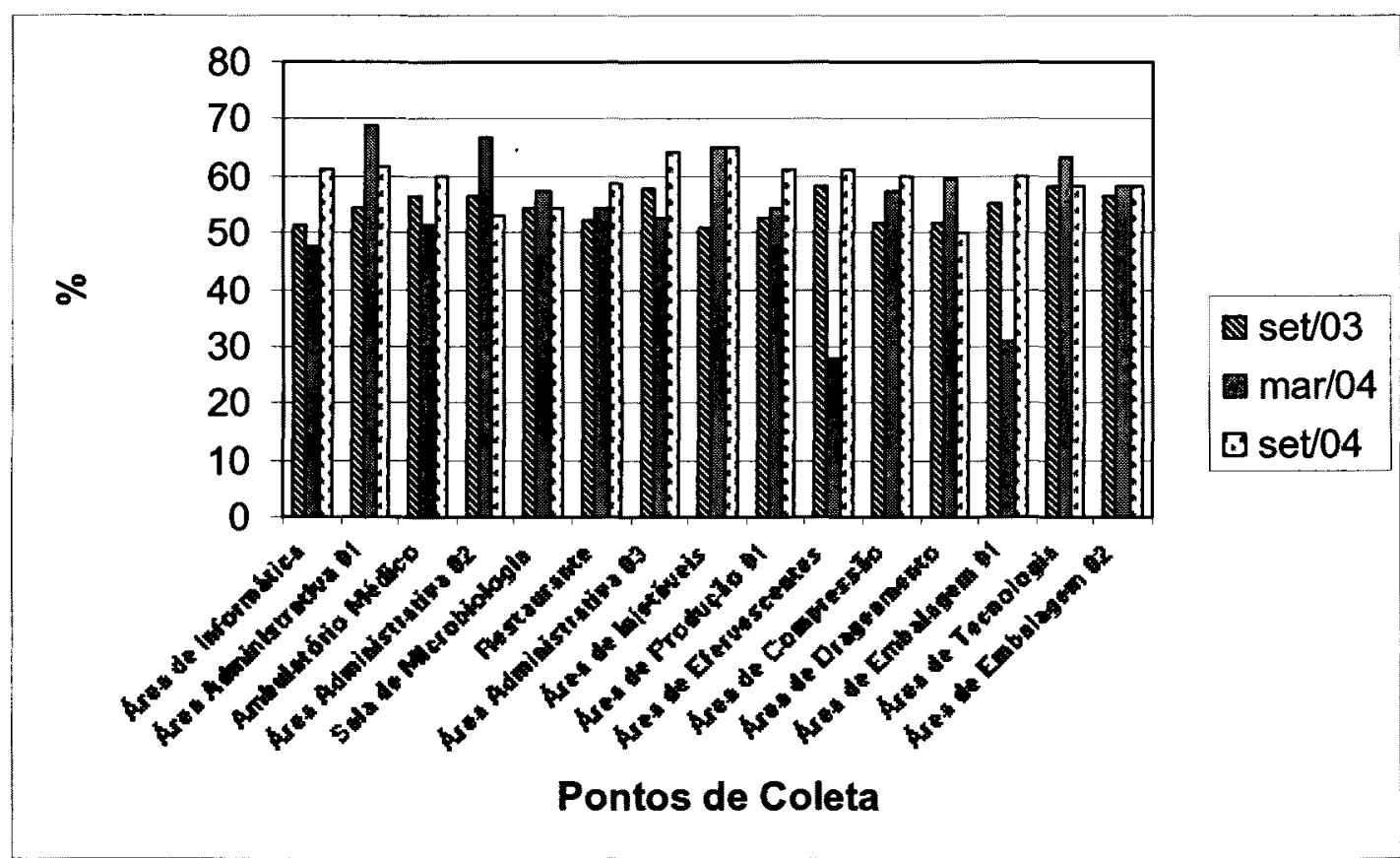

Gráfico 09: Resultados de monitoramento de umidade amostrados em 15 pontos.

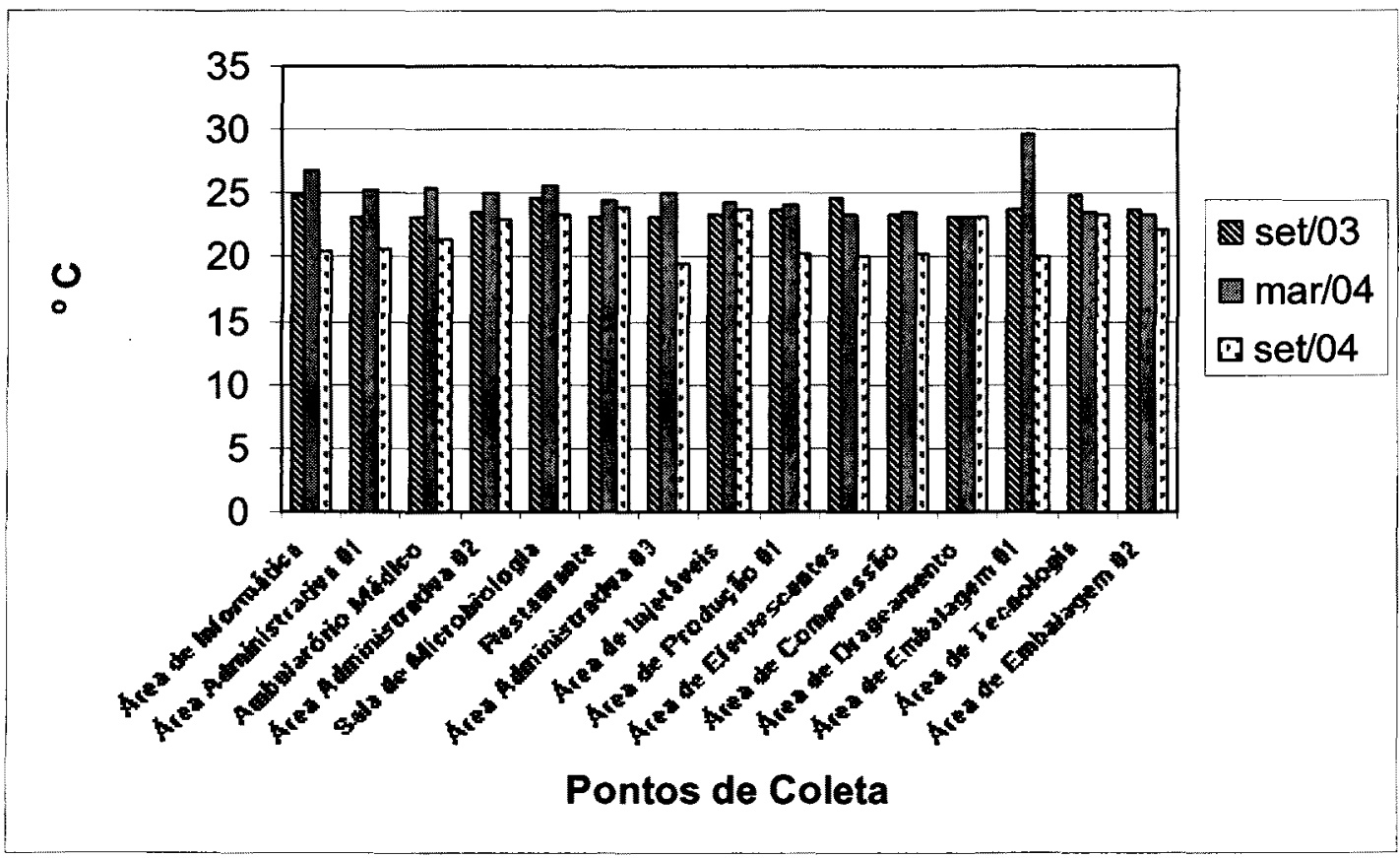

Gráfico 10: Resultados de monitoramento de temperatura amostrados em 15 pontos. 
Os valores obtidos para umidade e temperatura demonstram alinhamento com a faixa recomendada pela legislação (40 a 65\% para umidade e 23 a $26^{\circ} \mathrm{C}$ para a temperatura), sem evidências de que os dois pontos, que apresentaram acima dos valores para umidade e um para a temperatura, tivessem provocado qualquer tipo de comprometimento aos funcionários envolvidos no local.

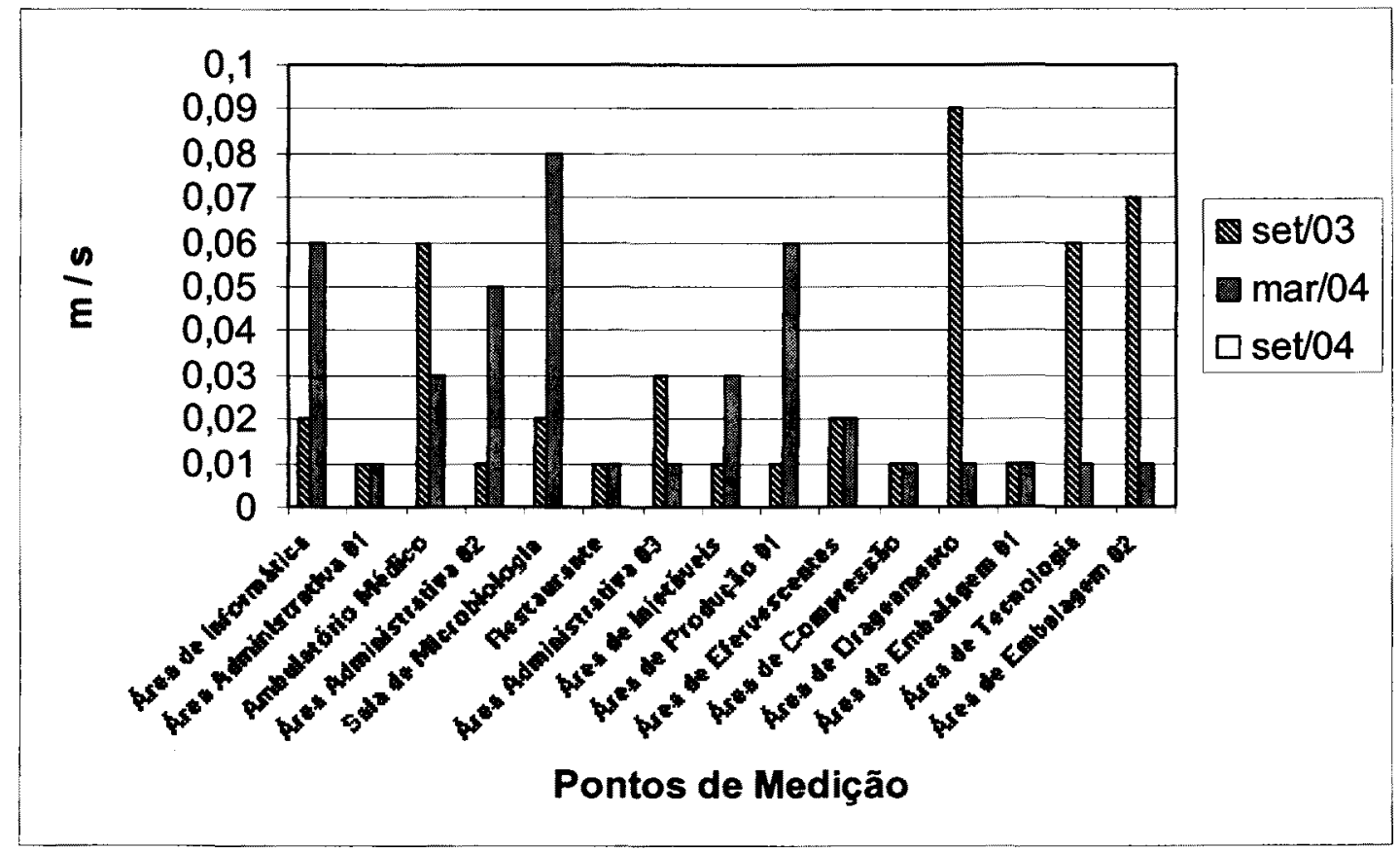

Gráfico 11: Resultados de monitoramento da velocidade do ar amostrados em 15 pontos.

O parâmetro de velocidade tem significativa importância pois, além de impactar no conforto, pode auxiliar o transporte de poluentes sejam eles químicos, físicos ou biológicos de dentro dos sistemas de ar condicionado para os ambientes climatizados. Os valores obtidos encontram-se dentro dos padrões estabelecidos, sendo que para a coleta de setembro, os resultados que estão mencionados na Tabela 09 apresentaram-se sempre abaixo dos $0,25 \mathrm{~m} / \mathrm{s}$ recomendados. 


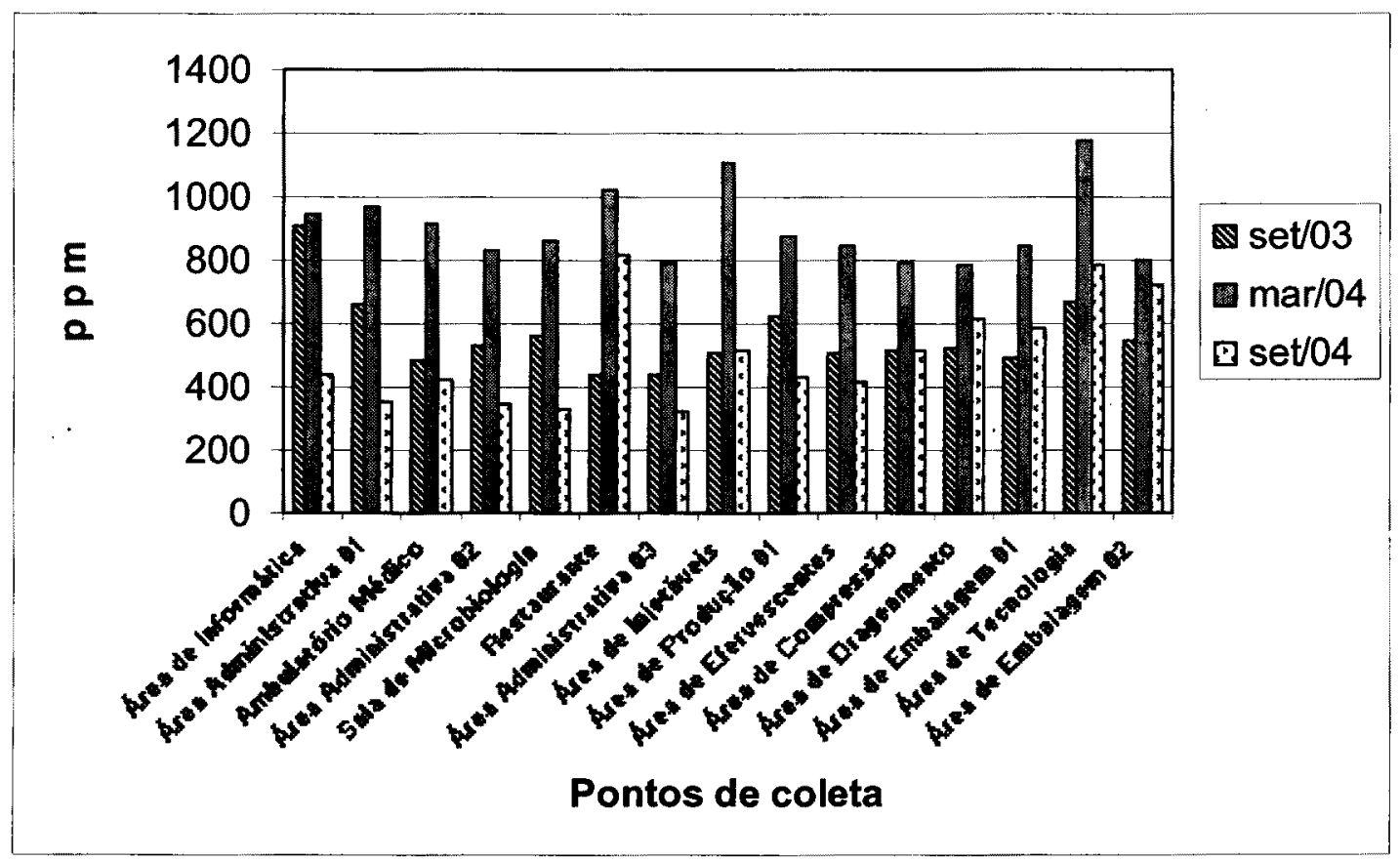

Gráfico 12: Resultados de monitoramento da concentração de dióxido de carbono amostrados em 15 pontos.

Os resultados de dióxido de carbono são de significativa importância, pois mesmo sendo um gás eliminado pelo processo da respiração humana, podem identificar que a fonte de coleta de ar exterior está comprometida por alguma fonte especifica, identificando a necessidade de mudança de local.

Os valores, obtidos nas coletas, apresentaram-se em geral abaixo dos limites estabelecidos (1.000 ppm), sendo que para aqueles onde os limites foram superados, não foram identificadas distúrbios ou reclamações, fruto desta concentração. A oscilação ocorrida na segunda campanha (março 2.004) não se repetiu na terceira coleta (setembro de 2.004 ), não se fazendo necessária nenhuma ação emergencial de controle. 


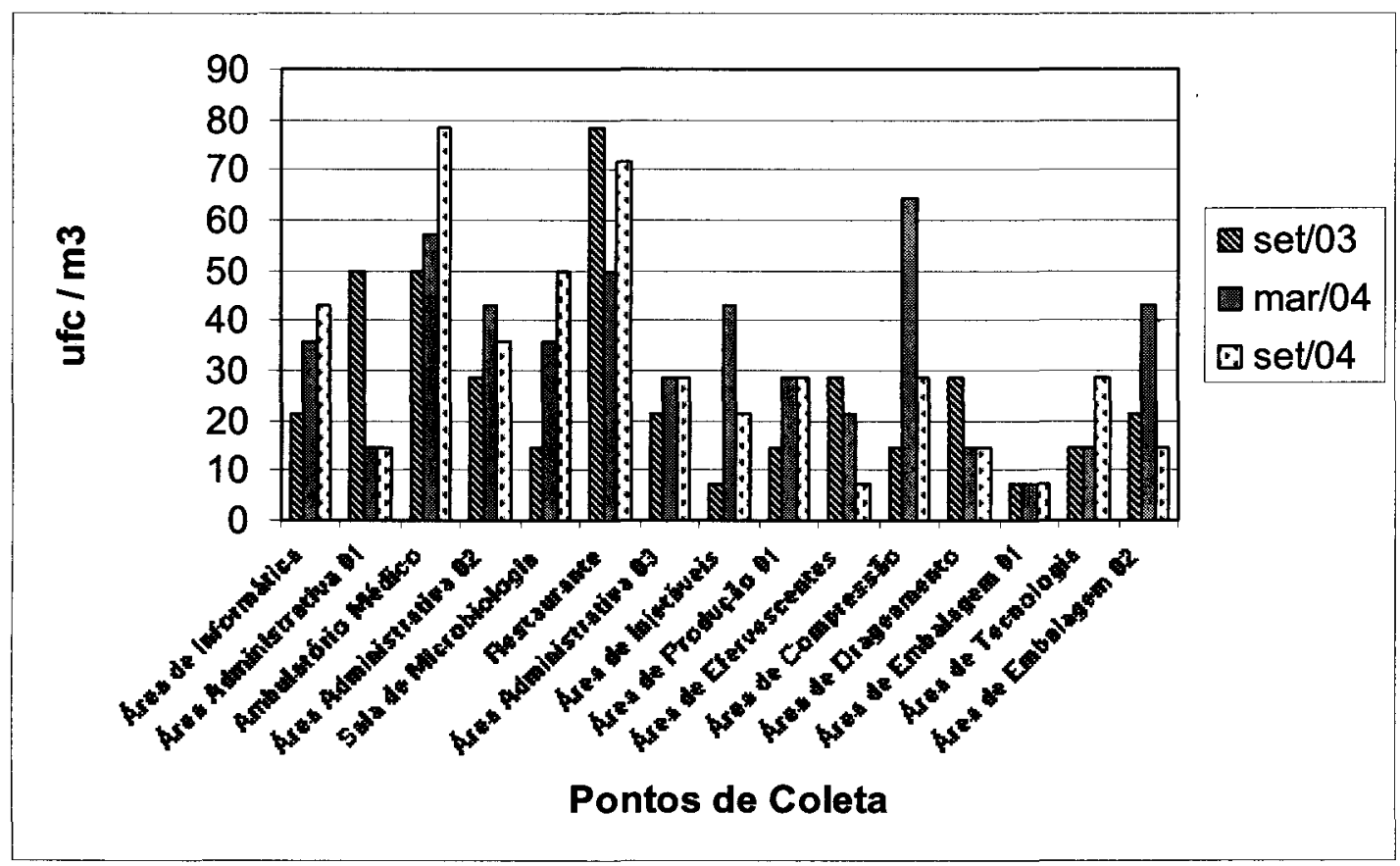

Gráfico 13: Resultados de monitoramento da concentração de fungos amostrados em 15 pontos.

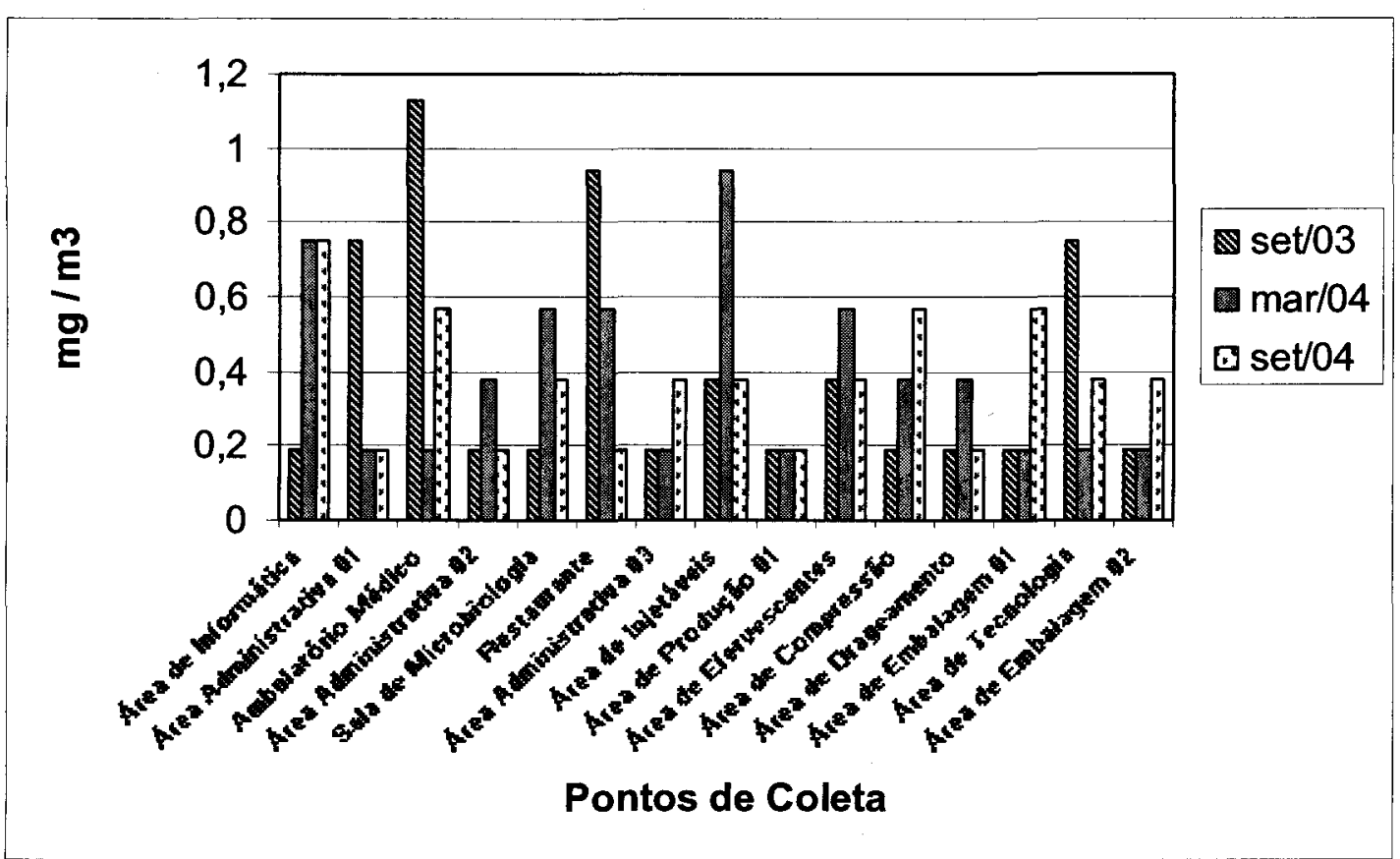

Gráfico 14: Resultados de monitoramento da concentração de material particulado amostrados em 15 pontos. 


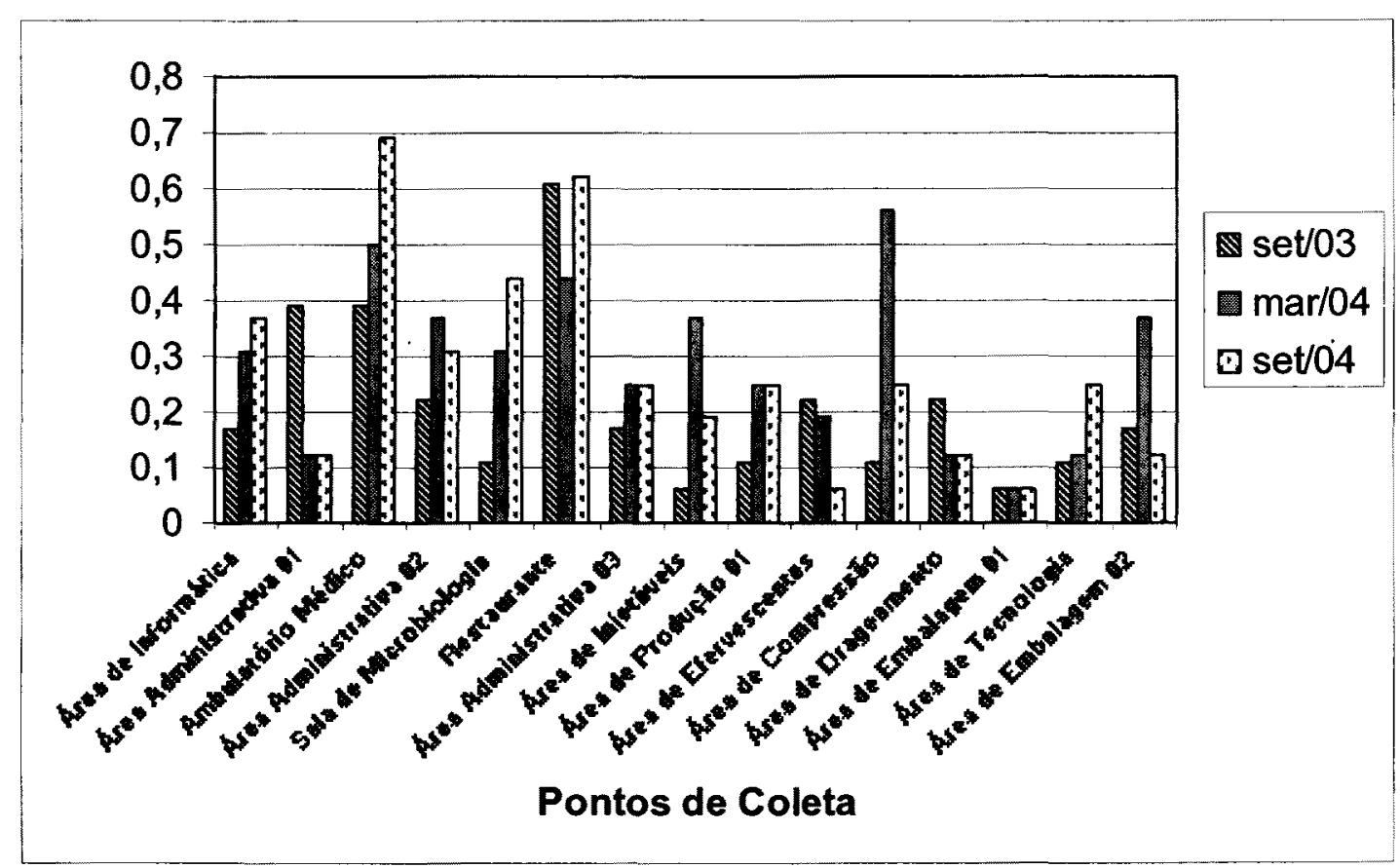

Gráfico 15: Resultados de monitoramento da relação da concentração de fungos presentes no ambiente interior e no ar exterior calculado para os 15 pontos.

Os valores indicados nos gráficos 13, 14 e 15 são os mais significativos em virtude de estarem relacionados com os principais focos de doenças originadas em sistemas de ar condicionado ( poluentes físicos e biológicos).

Destaca-se que os valores mais elevados, obtidos nas três campanhas, ficaram entre 40 e $50 \mathrm{ufc} / \mathrm{m}^{3}$ para a concentração de fungos e $1,2 \mathrm{mg} / \mathrm{m}^{3}$ para o material particulado, quando os limites estabelecidos são $750 \mathrm{ufc} / \mathrm{m}^{3}$ e $80 \mathrm{mg} / \mathrm{m}^{3}$ respectivamente.

Deve-se ressaltar ainda a relação entre o ar interior e o ar exterior que também deve ser atendido (abaixo de 1,5) isto é, mesmo tendo obtido valor reduzido nas concentrações de fungos, pois estes devem estar sempre abaixo uma vez e meia do valor do ar exterior. Os valores encontrados não ultrapassaram $50 \%$ deste limite. 
Estes resultados retratam que as práticas de manutenção foram implementadas de maneira consistente e estruturada. Apesar de não existirem registros de queixas relacionados aos sintomas ou doenças originárias nos sistemas de ar condicionado, a existência de um programa de manutenção padronizado, mesmo antes do início das campanhas de coleta, garantiu a homogeneidade das práticas sem interferir nos valores da concentração de fungos e material particulado durante os doze meses, período em que o estudo foi realizado.

Pelos resultados dos trabalhos anteriormente apresentados, fica evidente que este período seria suficiente para a proliferação de fungos e bactérias, caso um ambiente favorável estivesse "disponível" em qualquer equipamento integrante do sistema de ar condicionado.

Outro ponto de destaque é que o estudo foi efetuado em diferentes áreas da empresa, ficando diagnosticado que as práticas relativas aos sistemas de ar condicionado que possuem outros requisitos específicos e estão diretamente relacionadas com a qualidade do produto, podendo ter interferência significativa na mesma, são exatamente as que foram aplicadas nos demais sistemas de ar condicionado da fábrica. 


\section{CONCLUSÃo}

A partir da comprovação da existência de poluentes físicos, químicos e biológicos em ambientes climatizados, de doenças relacionadas à exposição destes poluentes, pela recomendação de práticas de manutenção e de definição de

parâmetros quantitativos presentes na legislação, os resultados apresentados e discutidos neste trabalho evidenciam a importância das ações de prevenção como forma de minimizar ou eliminar os principais sintomas ou eventualmente as doenças originárias em ambientes com temperatura controlada.

A exposição a poluentes existentes em ambientes climatizados ocorre freqüentemente, uma vez que se passa quase $80 \%$ do tempo em ambientes fechados, climatizados ou não, aumentando de forma significativa os riscos e reforçando a importância da implementação de ações preventivas.

Apesar de terem sido recentemente publicados - Plano de Manutenção, Operação e Controle no ano de 1.998 e os parâmetros quantitativos em 2.000 - os critérios legais aplicáveis aos sistemas de ar condicionado são de fácil entendimento e aplicação, garantindo que o atendimento aos parâmetros estabelecidos praticamente eliminam os riscos causados pelos sistemas de ar condicionado.

A existência de parâmetros quantitativos para os poluentes, principalmente os físicos e os biológicos, permite a realização de estudos comparativos de conclusão direta, identificando as necessidades de medidas corretivas para os casos de superação dos limites ou preventivas, se os valores estiverem próximos aos estabelecidos. 
Outro ponto de destaque é que as metodologias de análise de ar ambiental se mostram suficientemente sensíveis para detectar variações da qualidade do ar de ambientes interiores, decorrentes de procedimentos de higienização dos sistemas de ar condicionado. Além disso, a realização periódica de coletas e análises microbiológicas da qualidade do ar permite traçar um perfil e um histórico da contaminação nas instalações.

Desta forma é possível não somente identificar a necessidade de readequação dos processos de limpeza planejados, como também validar os procedimentos de manutenção. Ressalta-se também a importância da padronização dos mesmos com o intuito de eliminar riscos de variação da forma de aplicação, pois, como evidenciado nos resultados apresentados, desvios, na forma de execução da atividade, comprometem diretamente os valores.

Os resultados dos estudos analíticos, sejam os constantes na literatura como o efetuado no estudo piloto aqui apresentado, demonstram que a prática de ações de manutenção, como, por exemplo, a higienização dos equipamentos minimiza significativamente os impactos provocados por poluentes presentes nos sistemas de ar condicionado, isto é, existe estreita correlação entre a qualidade do ar de interiores e os procedimentos de higienização das superfícies fixas.

Assim os processos de higienização devem ser considerados de extrema importância na manutenção da qualidade do ar de interiores, tornando-os desta forma um item de elevado interesse em Saúde Pública.

Atualmente, vincula-se a noção de qualidade de vida e de saúde pública, ao gerenciamento do meio ambiente, passando-se a identificar as expectativas e as 
necessidades sociais e, conseqüentemente, a criar instrumentos que sirvam e permitam a sua aplicação de maneira apropriada.

A prática de higienização de dutos, em sistemas de ar condicionado central e outros de menor porte, é culturalmente inexistente no Brasil, uma vez que os projetos de instalação de sistemas de ar condicionado antiquados, em função da forma do tipo do projeto, não permitem o acesso a pontos críticos que devem obrigatoriamente fazer parte do programa de manutenção.

Para um bom administrador de programas de manutenção de sistemas de climatização ambiental, ou, simplesmente, administrador de ambientes, o conhecimento dos poluentes observados em ambientes interiores e que afetam não somente o conforto e o bem-estar, mas sobretudo, interferem diretamente na saúde dos usuários é requisito básico para permitir a adoção de medidas apropriadas dentro de prazos esperados ou planejados.

Algumas vezes as ações de manutenção dos sistemas de ar condicionado acabam sendo negligenciadas e, geralmente, definidas pelo menor custo, sem a preocupação com a qualidade de manutenção dos equipamentos e muito menos com a qualidade do ar que será fornecido ao público usuário.

Apesar do tema de custos não ter sido abordado de maneira enfática durante o trabalho, deve ser realçado, uma vez que é uma das principais preocupações para os empresários e administradores.

Os custos anuais necessários para melhorar as condições ambientais interiores, com ações corretivas como o aumento das taxas de renovação do ar, o aumento do grau de filtragem, a implementação de práticas sistemáticas e padronizadas de manutenção, foram estimadas de 18 a 47 vezes inferiores às 
economias potenciais com ganho de produtividade, diminuição dos casos de doenças respiratórias e sintomas alérgicos, asma e sintomas relacionados à síndrome dos edificios doentes.

Mesmo admitindo que os efeitos da exposição continuada a poluentes químicos, físicos e biológicos variam de maneira significativa em função da característica do poluente, do tempo de exposição, da susceptibilidade do ser humano entre outros, estima-se obter reduções entre $20 \%$ e $50 \%$ dos sintomas de doenças com as melhorias das condições ambientais do ar de interiores.

Portanto, fica evidente que os procedimentos de manutenção são necessários para redução e controle da microbiota existente nos sistemas de ar condicionado com o intuito de evitar o comprometimento da saúde do trabalhador nos ambientes interiores, especialmente às correlacionadas com as possíveis respostas alérgicas e / ou infecciosas das vias aéreas respiratórias.

Adicionalmente ao programa de manutenção, que deve considerar obrigatoriamente as ações focadas diretamente aos componentes do sistema de ar condicionado como: limpeza dos dutos de insuflamento e de retorno, tratamento das bandejas de condensado, limpeza ou substituição dos filtros, outras ações de controle de fontes de poluentes também são indispensáveis:

- criação de local específico para fumantes fora da área coberta pelo sistema de ar, evitando-se a circulação e contaminação ambiental pelos agentes químicos do cigarro; 
- isolamento das bocas de ventilação e exaustão, em áreas ocupadas por máquinas copiadoras, evitando também a contaminação do sistema por contaminantes químicos, gerados no funcionamento e na manutenção das mesmas,

- controle da eficiência das capelas, em áreas de laboratório, servidas pelo sistema central de ar condicionado e

- adequação dos pontos de captação de ar externo, distanciando-os ao máximo de fontes de poluição.

Para que o programa de manutenção seja eficaz, é preciso também definir a periodicidade das ações que deve estar alinhada com os padrões estabelecidos na legislação (Portaria 3.523 do Ministério da Saúde). Pode ser feita através dos resultados dos monitoramentos de poluentes efetuados e comparados com os parâmetros estabelecidos (Resolução 176 e 09 da ANVISA), definindo eventuais necessidades de aumento ou diminuição da freqüência das ações programadas.

Devem-se incluir aos programas de manutenção, alguns cuidados criteriosos e práticas administrativas, destacando:

- durante a execução de alterações nas áreas administrativas, como mudança de revestimento, de pisos, divisórias, de alvenaria ou pintura, isolar adequadamente a área, impedindo a contaminação do sistema de ar condicionado por materiais particulados e / ou poluentes químicos, 
- instalação de programa de monitoramento, uma vez que ficou demonstrada a importância e a representatividade dos resultados obtidos como indicativos de problemas nos sistemas de ar condicionado e

- monitoramento e acompanhamento constante das avaliações realizadas pelo serviço médico e de saúde, responsável por registrar e comunicar possíveis sintomas ou sinais relacionados às alterações da qualidade do ar ambiental.

A implementação das práticas recomendadas de maneira consistente e padronizada garante seguramente a minimização da concentração de poluentes físicos, químicos e biológicos nos sistemas de ar condicionado, tendo como principal conseqüência, avaliado claramente como benefício significativo, a redução das doenças originárias em sistemas de ambiente climatizado. 


\section{BIBLIOGRAFIA}

I. Dantas E H M, Ar condicionado vilão ou aliado? Uma revisão crítica. Revista Brasindoor. São Paulo; 1998, v. 2, nº 9, p.4-9.

II. Siqueira L F G, Silveira M J, Ferreira L A P. A gestão ambiental das edificações. Revista Brasindoor. São Paulo; 2002. v. 6, nº 4, p.4-11.

III. Dantas E H M, Ricard I, Controle de fontes poluentes em sistemas de ar condicionado. Revista Brasindoor. São Paulo; 2000. v. 4, n 3, p.4-9.

IV. Riello S, Dantas E H M, Ricard I, Manutenção em condicionadores para a garantia da qualidade de ar. Revista Brasindoor. São Paulo; 1999, v. 3, nº 1, p.4-8.

V. Fanger $\mathrm{P} O$, Human requirements in future air condtioned environments. Revista Brasindoor. São Paulo; 2001. v. 5, nº 2, p.1-5.

VI. Siqueira L F G, Cattapan A, Belda, W J, Fagundes L J, Cattapan E, O meio ambiente, a saúde do ser humano contemporâneo e a qualidade de vida. $O$ conhecimento e a prevenção. Revista Brasindoor. São Paulo; 2002. v. 6, nº 2, p.4-9. 
VII. Aquino N F R, Brickus, L S R, Padrões referenciais para análise de resultados de qualidade físico-química do ar em interiores visando à saúde pública. Revista Brasindoor. São Paulo; 1.999. v. 3, nº 2, p.4-15.

VIII. Siqueira L F G, Dantas E H M, Organização e métodos no processo de avaliação da qualidade do ar de interiores. Revista Brasindoor. São Paulo; 1.999. v.3, $n^{\circ} 2$, p.19-25.

IX. Pimenta R B, Pimenta C, Avaliação da fonte poluente primária em sistemas de ar condicionado central e a qualidade do ar no ambiente de trabalho. Diagnóstico e Intervenção. Revista Brasindoor. São Paulo; 1.997. v. 2 , nº 6, p.4-11.

X. Siqueira L F G, Cardoso M R A, Silveira M J, A interferência do processo de higienização na qualidade de ar de interiores. Revista Brasindoor. São Paulo; 1.997 . v. $2, \mathrm{n}^{\mathrm{o}} 6, \mathrm{p} .12-18$.

XI. Savin G, Legislação ambiental e a qualidade do ar de interiores. Revista Brasindoor. São Paulo; 2.000. v. $4, \mathrm{n}^{\circ} 1, \mathrm{p} .4-7$.

XII. Alexandre C C S, Technik T, A qualidade do ar e a contribuição do sistema de ar condicionado. Revista Brasindoor. São Paulo; 1.996. v. 1, nº 2, p.4-8. 
XIII. Souza M L P, Silveira J S , Siqueira L F G, Programas de higienização e a qualidade de ar de interiores. Revista Brasindoor. São Paulo; 1.996. v. 1, $\mathrm{n}^{\mathrm{o}} 2, \mathrm{p} \cdot 15-23$.

XIV. Siqueira L F G, Silveira M J, Avaliação da capacidade de retenção de matéria particulada em equipamento destinado à purificação de ar de ambientes. Revista Brasindoor. São Paulo; 2.000. v. 4, n² 2, p.4-7.

XV. Brasil. Portaria do Ministério da Saúde $\mathrm{n}^{\circ} 3.523$ de 28 de agosto de 1.998 Aprova o Regulamento Técnico contendo medidas básicas referentes ao procedimento de verificação visual do estado de limpeza, remoção de sujidades por métodos físicos e manutenção do estado de integridade e eficiência de todos os componentes dos sistemas de climatização, para garantir a qualidade do ar de interiores e prevenção de riscos à saúde dos ocupantes de ambientes climatizados. Diário Oficial da União, Brasília, 29 agosto 1998.

XVI. Brasil. Resolução Agência Nacional de Vigilância Sanitária RE-176 de 24 de outubro de 2000 - Determina a publicação de Orientação Técnica elaborada por grupo técnico assessor, sobre padrões referenciais de qualidade do ar interior, em ambientes climatizados artificialmente de uso público e coletivo. Diário Oficial da União, Brasília, 25 outubro 2000. 
XVII. Brasil. Resolução Agência Nacional de Vigilância Sanitária RE-nº 09 de 16 de janeiro de 2.003 - Determina a publicação de Orientação Técnica elaborada por grupo técnico assessor, sobre padrões referenciais de qualidade do ar interior, em ambientes climatizados artificialmente de uso público e coletivo. Diário Oficial da União, Brasília, 20 janeiro 2.003 .

XVIII. Iwamoto S, Utsunomiya $\mathrm{A}$, Ooishi $\mathrm{O}$, Behavior of airborne particulates in urban spaces and its surroundings. J. Japan Soc. Air Pollution, 25:170-9, 1.990 .

XIX. Takahashi S, Kubota Y, Sato H, Esaka F, Nakamoto R, Furuya K, Size distribution of suspended particulate matter in underground and above ground air and their deposition ratios in human respiratory tract. Proceedings of Indoor Air, 1.996. v. 2, p.79-84.

XX. Yotsuyanagi T, Surveillance systems for health effects in artificial urban environment, report of "Formulation and management of man environment system, Support by Grant in Aid for Scientific Research, Ministry of Education, Culture and Science, Japan. Report $\mathrm{n}^{\circ} \mathrm{G} 082-\mathrm{N} 38 \mathrm{~B}-01$, 1.993.

XXI. Nicholls P J, Vegetables dusts and lung diseases. Indoor Air Pollutions. Problems and Priorities. Cambridge University Press; 1994. p. 161-182. 
XXII. Cardoso B, Qualidade do Ar é responsável por $10 \%$ das Infecções hospitalares Revista Brasindoor. São Paulo; 1.999. v. 3, no 3, p.11-14.

XXIII. Cardoso B, Novos Rumos da Manutenção em sistemas de ar condicionado Revista Brasindoor. São Paulo; 2.000. v. 4, n 2, p.10-13.

XXIV. Siqueira L F G, Cattapan A, Belda W J, Fagundes L J, Cattapan E, O meio ambiente, o tabagismo e as doenças respiratórias. Mecanismos de ação, epidemiologia e prevenção. Revista Brasindoor. São Paulo; 2.002. v. 6, nº 3, p.4-10.

XXV. Holcátová I, Jirku V, Masák J, Oki M, Holcat M, Allergens and Allergies Is there a chance to reduce them? Revista Brasindoor. São Paulo; 2.001. v. 5, n³, p.11-13.

XXVI. Maroni M, Indoor air pollutants and related health effects Revista Brasindoor. São Paulo; 2.002, v.5, no 3, p.1-5.

XXVII. Fanger P O, Human Requirements in future air conditioned environments Revista Brasindoor. São Paulo; 2.001. v.5, no 2, p.1-5.

XXVIII. Rylander R, Elementos da Parede Celular Microbiana e a sua relação com as doenças Revista Brasindoor. São Paulo; 1.999. v.3, n 1, p.20-21. 
XXIX. Andersson K, Enfoque epidemiológico para os problemas de qualidade de ar em ambientes fechados, Resenha. Revista Brasindoor. São Paulo; 1.999, v. $3, \mathrm{n}^{\circ} 1, \mathrm{p} .22-23$.

XXX. Molhave L, Princípios para avaliação dos efeitos da poluição em ambientes fechados no conforto e sobre a saúde. Revista Brasindoor. São Paulo; 1.999 v. $3, \mathrm{n}^{\mathrm{o}} 1, \mathrm{p} .23-24$. 